\title{
From Town Center to Shopping Center: The Reconfiguration of Community Marketplaces in Postwar America
}

\section{Citation}

Cohen, Lizabeth. 1996. From town center to shopping center: The reconfiguration of community marketplaces in postwar America. American Historical Review 101(4): 1050-1081.

\section{Published Version}

doi: $10.2307 / 2169634$

\section{Permanent link}

http://nrs.harvard.edu/urn-3:HUL.InstRepos:4699748

\section{Terms of Use}

This article was downloaded from Harvard University's DASH repository, and is made available under the terms and conditions applicable to Other Posted Material, as set forth at http:// nrs.harvard.edu/urn-3:HUL.InstRepos:dash.current.terms-of-use\#LAA

\section{Share Your Story}

The Harvard community has made this article openly available. Please share how this access benefits you. Submit a story.

Accessibility 


\title{
AHR Forum \\ From Town Center to Shopping Center: The Reconfiguration of Community Marketplaces in Postwar America
}

\author{
LIZABETH COHEN
}

WHEN THE EDITORS OF TIME MAGAZINE set out to tell readers in an early January 1965 cover story why the American economy had flourished during the previous year, they explained it in terms that had become the conventional wisdom of postwar America. The most prosperous twelve months ever, capping the country's fourth straight year of economic expansion, were attributable to the American consumer, "who continued spending as if there were no tomorrow." According to Time's economics lesson, consumers, business, and government "created a nonvicious circle: spending created more production, production created wealth, wealth created more spending." In this simplified Keynesian model of economic growth, "the consumer is the key to our economy." As R. H. Macy's board chair Jack Straus explained to Time's readers, "When the country has a recession, it suffers not so much from problems of production as from problems of consumption." And in prosperous times like today, "Our economy keeps growing because our ability to consume is endless. The consumer goes on spending regardless of how many possessions he has. The luxuries of today are the necessities of tomorrow." A demand economy built on mass consumption had brought the United States out of the doldrums of the Great Depression and World War II, and its strength in the postwar period continued to impress those like retail magnate Straus whose own financial future depended on it. ${ }^{1}$

Although Straus and his peers invested great energy and resources in developing new strategies for doing business in this mass-consumption economy, historians

I would like to acknowledge the skill and imagination of two research assistants, Deb Steinbach and Susan Spaet. My research was supported by grants from the National Endowment for the Humanities (1993), the American Council of Learned Societies (1994), and New York University (1993-1994). I am also grateful to several audiences who shared helpful reactions to versions of this article: the international conference "Gender and Modernity in the Era of Rationalization," Columbia University, September 1994; the conference "Significant Locales: Business, Labor, and Industry in the MidAtlantic Region," sponsored by the Center for the History of Business, Technology, and Society, Hagley Museum and Library, October 1994; the history department at George Washington University, February 1995; Tricia Rose's American Studies Colloquium, New York University, February 1995; the Historians of Greater Cleveland, May 1995; and my audience at Vassar College, November 1995. Individuals whose readings have especially helped me include Herrick Chapman, Michael Ebner, Ken Jackson, Richard Longstreth, Tricia Rose, Phil Scranton, David Schuyler, Sylvie Schweitzer, and two anonymous readers for the $A H R$.

1 "The Economy: The Great Shopping Spree," Time (January 8, 1965): 58-62 (and cover). 
have paid far less attention to the restructuring of American commercial life in the postwar period than to the transformation of residential experience. An impressive literature documents the way the expansion of a mass consumer society encouraged a larger and broader spectrum of Americans to move into suburban communities after the war. ${ }^{2}$ Between 1947 and 1953 alone, the suburban population increased by 43 percent, in contrast to a general population increase of only 11 percent. ${ }^{3}$ At an astonishing pace, the futuristic highways and mass-built, appliance-equipped, single-family homes that had been previewed at the New York World's Fair in 1939-1940 seemed to become a reality. Thanks to a shortage in urban housing, government subsidies in highway building and home construction or purchase, and pent-up consumer demand and savings, a new residential landscape began to take shape in metropolitan areas, with large numbers of people commuting into cities for work and then back to homes in the suburbs. (Increasingly as the postwar era progressed, suburbanites worked, not just lived, outside cities.)

Less explored by historians and slower to develop historically was the restructuring of the consumer marketplace that accompanied the suburbanization of residential life. New suburbanites who had themselves grown up in urban neighborhoods walking to corner stores and taking public transportation to shop downtown were now contending with changed conditions. Only in the most ambitious suburban tracts built after the war did developers incorporate retail stores into their plans. In those cases, developers tended to place the shopping district at the core of the residential community, much as it had been in the pre-war planned community of Radburn, New Jersey, and in the earliest shopping centers, such as Kansas City's Country Club Plaza of the 1920s. These precedents, and their descendents in early postwar developments in Park Forest, Illinois, Levittown, New York, and Bergenfield, New Jersey, replicated the structure of the old-style urban community, where shopping was part of the public space at the settlement's core and residences spread outward from there. ${ }^{4}$ But most new suburban home developers made no effort to provide for residents' commercial needs. Rather, suburbanites were expected to fend for themselves by driving to the existing

${ }^{2}$ See Kenneth T. Jackson, Crabgrass Frontier: The Suburbanization of the United States (New York, 1985); Robert Fishman, Bourgeois Utopias: The Rise and Fall of Suburbia (New York, 1987); Joel Garreau, Edge City: Life on the New Frontier (Garden City, N.Y., 1991); William Sharpe and Leonard Wallock, "Bold New City or Built-Up 'Burb? Redefining Contemporary Suburbia," with comments by

$\rightarrow$ Robert Bruegmann, Robert Fishman, Margaret Marsh, and June Manning Thomas, American Quarterly 46 (March 1994): 1-1 $\rightarrow$ Carol O’Connor, "Sorting Out Suburbia," American Quarterly 37 (Summer 1985): 382-94.

3 The Editors of Fortune, The Changing American Market (Garden City, N.Y., 1995), 76.

${ }^{4}$ Ann Durkin Keating and Ruth Eckdish Knack, "Shopping in the Planned Community: Evolution of the Park Forest Town Center," unpublished paper in possession of auth $\rightarrow$ Howard Gillette, Jr., "The Evolution of the Planned Shopping Center in Suburb and City," American Planning Association Journal 51 (Autumn 1985): 449-60; Daniel Prosser, "The New Downtowns: Commercial Architecture in Suburban New Jersey, 1920-1970," in Joel Schwartz and Daniel Prosser, Cities of the Garden State: Essays in the Urban and Suburban History of New Jersey (Dubuque, Iowa, 1977), 113-15; "Park Forest Moves into '52," House and Home: The Magazine of Building 1 (March 1952): 115-16; William S. Worley, J. C. Nichols and the Shaping of Kansas City: Innovation in Planned Residential Communities (Columbia, Mo., 1990); Richard Longstreth, "J. C. Nichols, the Country Club Plaza, and Notions of Modernity," The Harvard Architecture Review, Vol. 5: Precedent and Invention (New York, 1986), 121-32; William H. Whyte, Jr., "The Outgoing Life," Fortune 47 (July 1953): 85; Michael Birkner, $A$ Country Place No More: The Transformation of Bergenfield, New Jersey, 1894-1994 (Rutherford, N.J., 1994), 174-77; Bergen Evening Record, Special Foster Village Edition, August 10, 1949. 
"market towns," which often offered the only commerce for miles, or by returning to the city to shop. Faced with slim retail offerings nearby, many new suburbanites of the 1940s and 1950s continued to depend on the city for major purchases, making do with the small, locally owned commercial outlets in neighboring towns only for minor needs.

It would not be until the mid-1950s that a new market structure appropriate to this suburbanized, mass-consumption society prevailed. Important precedents existed in the branch department stores and prototypical shopping centers constructed between the 1920s and 1940s in outlying city neighborhoods and in older suburban communities, which began the process of decentralizing retail dollars away from downtown. But now the scale was much larger. Even more significant, the absence or inadequacy of town centers at a time of enormous suburban population growth offered commercial developers a unique opportunity to reimagine community life with their private projects at its heart. ${ }^{5}$

By the early 1950s, large merchandisers were aggressively reaching out to the new suburbanites, whose buying power was even greater than their numbers. ${ }^{6}$ The 30 million people that Fortune magazine counted as suburban residents in 1953 represented 19 percent of the U.S. population but 29 percent of its income. They had higher median incomes and homeownership rates, as well as more children fourteen and under than the rest of the metropolitan population, all indicators of high consumption.

Merchandisers also realized that postwar suburbanites were finally living the motorized existence that had been predicted for American society since the 1920 s. As consumers became dependent on, virtually inseparable from, their cars, traffic congestion and parking problems discouraged commercial expansion in central business districts of cities and smaller market towns, already hindered by a short supply of developable space. ${ }^{7}$ Reaching out to suburbanites where they lived, merchandisers at first built stores along the new highways, in commercial "strips" that consumers could easily reach by car. By the mid-1950s, however, commercial developers-many of whom owned department stores-were constructing a new kind of marketplace, the regional shopping center aimed at satisfying suburbanites' consumption and community needs. Strategically located at highway intersections or along the busiest thoroughfares, the regional shopping center attracted patrons living within half an hour's drive, who could come by car, park in the abundant lots provided, and then proceed on foot (although there was usually some bus service as well). Here was the "new city" of the postwar era, a vision of how community space

5 Jackson, Crabgrass Frontier, 255-61. On precedents in the pre-World War II period, see Richard Longstreth, "Silver Spring: Georgia Avenue, Colesville Road, and the Creation of an Alternative 'Downtown' for Metropolitan Washington," in Streets: Critical Perspectives on Public Space, Zeynep Celik, Diane Favro, and Richard Ingersoll, eds. (Berkeley, Calif., 1994), 247-: $\rightarrow$ Longstreth, "The Neighborhood Shopping Center in Washington, D.C., 1930-1941," Journal of the Society of Architectural Historians 51 (March 1992): 5-33; Longstreth, "The Perils of a Parkless Town," in The Car and the City: The Automobile, the Built Environment, and Daily Urban Life, Martin Wachs and Margaret Crawford, eds. (Ann Arbor, Mich., 1992), 141-53.

${ }^{6}$ Editors of Fortune, Changing American Market, 78-80, 90. Also see "New Need Cited on Store Centers," New York Times (February 13, 1955): 7.

7 Richard Longstreth, “The Mixed Blessings of Success: The Hecht Company and Department Store Branch Development after World War II," Occasional Paper No. 14, January 1995, Center for Washington Area Studies, George Washington University. 
should be constructed in an economy and society built on mass consumption. Well-designed regional shopping centers would provide the ideal core for a settlement that grew by adding residential nodes off of major roadways rather than concentric rings from downtown, as in cities and earlier suburban communities. After spending several months in the late 1950s visiting these "modern-day downtowns," Women's Wear Daily columnist Samuel Feinberg was moved to invoke Lincoln Steffens's proclamation on his return from the Soviet Union in the 1920s: "I have seen the future and it works." 8

This essay will analyze the larger social and political implications of the shift in community marketplace from town center to shopping center. Although I draw on national evidence, I pay special attention to the case of Paramus, New Jersey, a postwar suburb seven miles from the George Washington Bridge that sprouted virtually overnight in the vegetable fields of Bergen County and became the home of the largest shopping complex in the country by the end of $1957.9^{9}$ Within six months, R. H. Macy's Garden State Plaza and Allied Stores Corporation's Bergen Mall opened three quarters of a mile from each other at the intersection of Routes 4, 17, and the soon-to-be-completed Garden State Parkway. Both department store managements had independently recognized the enormous commercial potential of Bergen and Passaic counties; although the George Washington Bridge connected the area to Manhattan in 1931, the Depression and the war postponed major housing construction until the late 1940s. By 1960, each shopping center had two to three department stores as anchors (distinguishing it from many pre-war projects built around a single anchor), surrounded by fifty to seventy smaller stores. Attracting half a million patrons a week, these shopping centers dominated retail trade in the region. ${ }^{10}$ (See Figures 1 and 2.)

The Paramus malls have special significance because of their location adjacent to the wealthiest and busiest central business district in the nation. If these malls could prosper in the shadow of Manhattan, the success of their counterparts elsewhere should come as no surprise. Moreover, the Paramus case illuminates three major effects of shifting marketplaces on postwar American community life: in commer-

${ }^{8}$ Samuel Feinberg, "Story of Shopping Centers," What Makes Shopping Centers Tick, reprinted from Women's Wear Daily (New York, 1960), 1. For useful background on the development of regional shopping centers, see William Severini Kowinski, The Malling of America: An Inside Look at the Great Consumer Paradise (New York, 1985); Neil Harris, Cultural Excursions: Marketing Appetites and Cultural Tastes in Modern America (Chicago, 1990), 7, 76-77, 278-88; Margaret Crawford, "The World in a Shopping Mall," in Michael Sorkin, ed., Variations on a Theme Park: The New American City and the End of Public Space (New York, 1992), 3-30; Gillette, "Evolution of the Planned Shopping Center."

${ }^{9} \mathrm{On}$ the postwar growth of Paramus and Bergen County, see Raymond M. Ralph, Farmland to Suburbia, 1920-1960, Vol. 6, Bergen County, New Jersey History and Heritage Series (Hackensack, N.J., 1983), 62-71, 76-90; Catherine M. Fogarty, John E. O’Connor, and Charles F. Cummings, Bergen County: A Pictorial History (Norfolk, Va., 1985), 182-93; Beautiful Bergen: The Story of Bergen County, New Jersey, 1962; Patricia M. Ryle, An Economic Profile of Bergen County, New Jersey (Office of Economic Research, Division of Planning and Research, New Jersey Department of Labor and Industry, March 1980); League of Women Voters of Bergen County, Where Can I Live in Bergen County: Factors Affecting Housing Supply (Closter, N.J., 1972).

${ }^{10}$ Feinberg, What Makes Shopping Centers Tick, 2, 94-102; Ralph, Farmland to Suburbia, 70-71, 84-85; Mark A. Stuart, Our Era, 1960-Present, Vol. 7, Bergen County, New Jersey History and Heritage Series (Hackensack, N.J., 1983), 19-22; Prosser, "New Downtowns," 119-20; Edward T. Thompson, "The Suburb That Macy's Built," Fortune 61 (February 1960): 195-200; "Garden State Plaza Merchant's Manual," May 1, 1957, and certain pages revised in 1959, 1960, 1962, 1963, 1965, 1969, Garden State Plaza Historical Collection. 


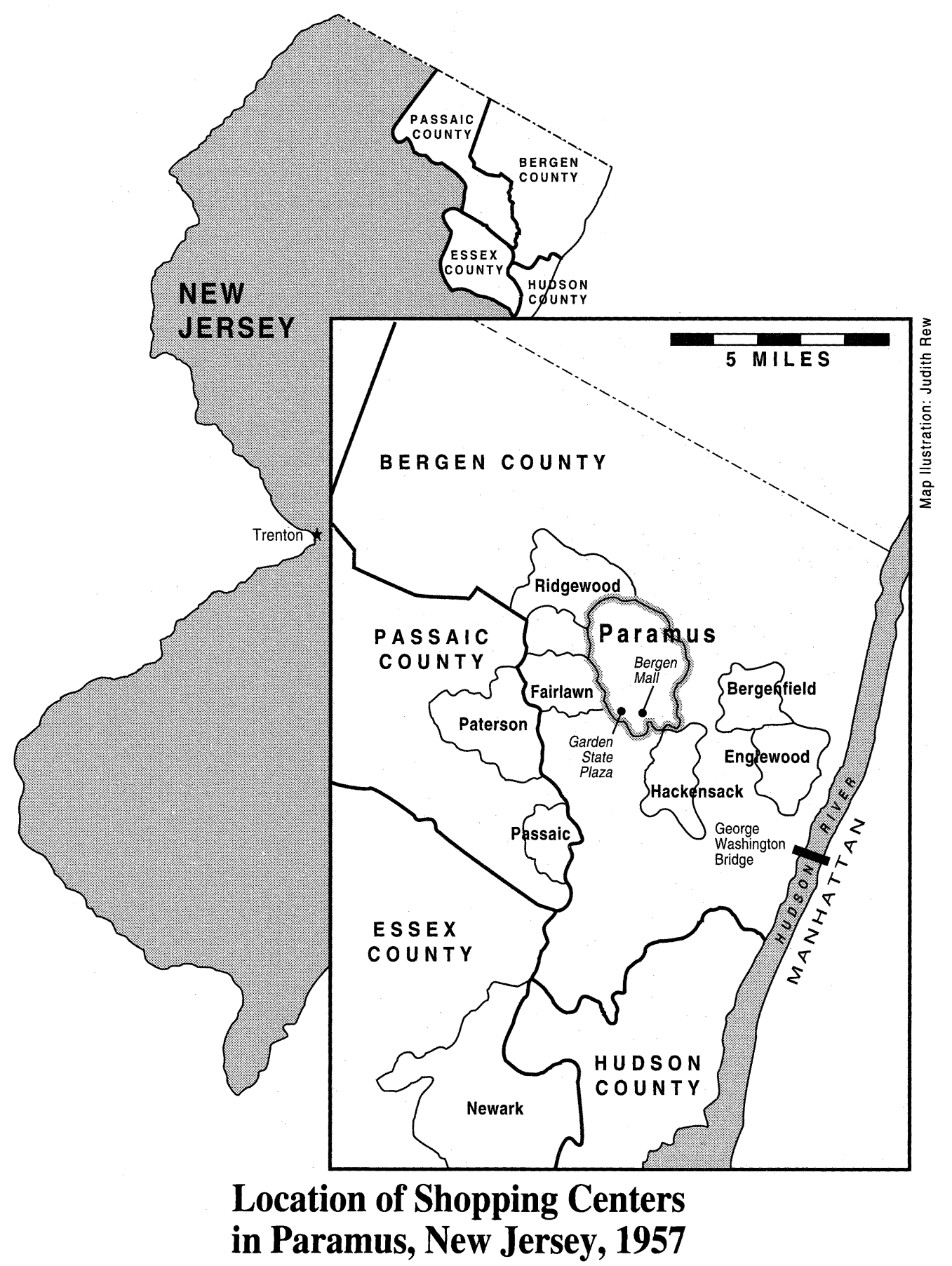

FIGURE 1

cializing public space, they brought to community life the market segmentation that increasingly shaped commerce; in privatizing public space, they privileged the rights of private property owners over citizens' traditional rights of free speech in 


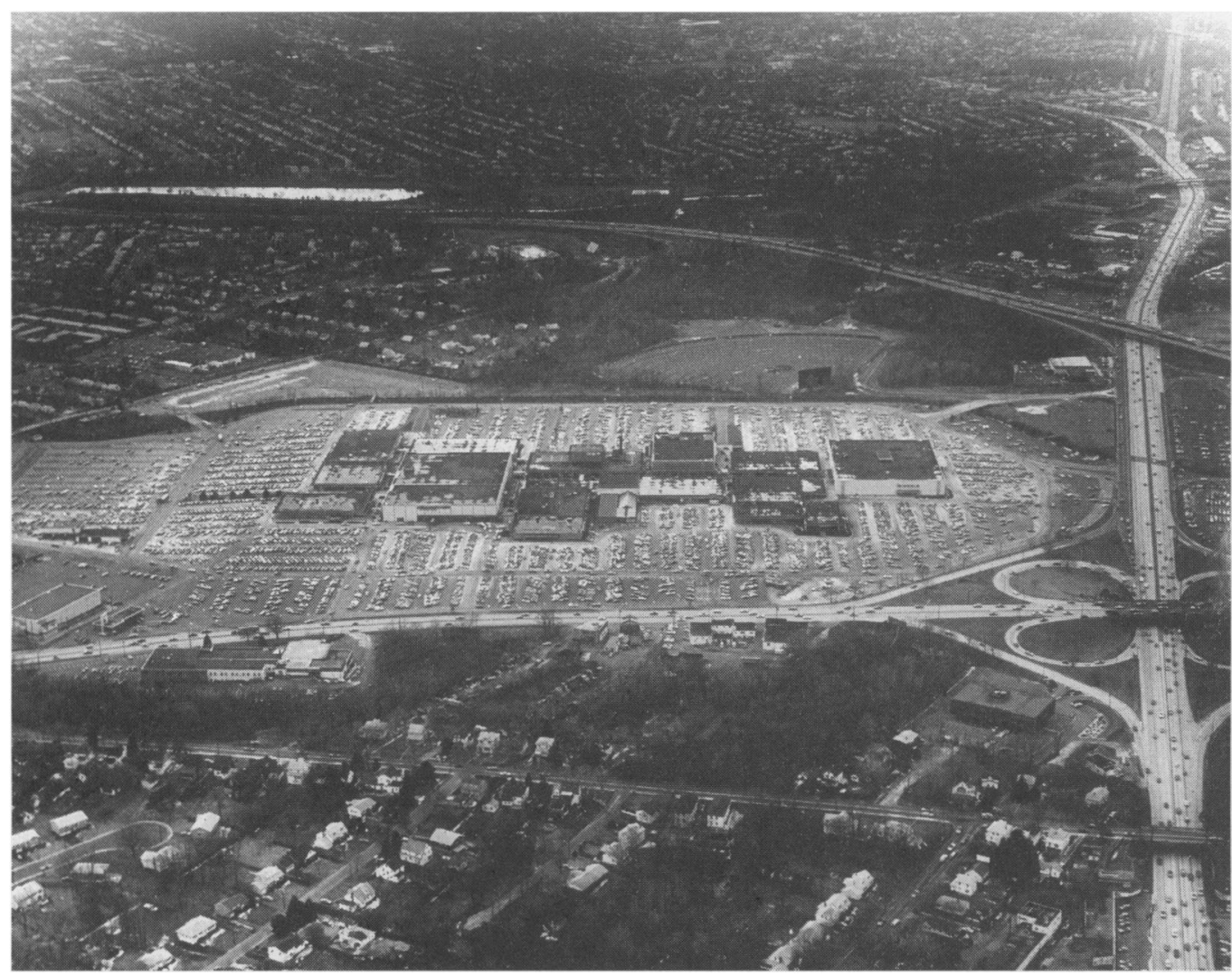

Figure 2: This aerial view of the Garden State Plaza in Paramus, New Jersey, shows its orientation to the car. Note its convenient location at the intersection of Routes 4 and 17 and the Garden State Parkway, as well as the extensive space allocated for parking. Courtesy of Garden State Plaza Historical Collection.

community forums; and in feminizing public space, they enhanced women's claim on the suburban landscape but also empowered them more as consumers than producers.

WHEN PLANNERS AND SHOPPING-CENTER DEVELOPERS envisioned this new kind of consumption-oriented community center in the 1950s, they set out to perfect the concept of downtown, not to obliterate it, even though their projects directly challenged the viability of existing commercial centers such as Hackensack, the political and commercial seat of Bergen County. It is easy to overlook this visionary dimension and focus only on the obvious commercial motives developers and investors shared. Of course, developers, department stores, and big investors such as insurance companies (who leapt at the promise of a huge return on the vast amounts of capital they controlled) were pursuing the enormous potential for profit in shopping-center development. ${ }^{11}$ But they also believed that they were participating in a rationalization of consumption and community no less significant than

11 On the financing of shopping centers and the great profits involved, see Jerry Jacobs, The Mall: An Attempted Escape from Everyday Life (Prospect Heights, Ill., 1984), 52. 
the way highways were improving transportation or tract developments were delivering mass housing.

The ideal was still the creation of centrally located public space that brought together commercial and civic activity. Victor Gruen, one of the most prominent and articulate shopping-center developers, spoke for many others when he argued that shopping centers offered to dispersed suburban populations "crystallization points for suburbia's community life." "By affording opportunities for social life and recreation in a protected pedestrian environment, by incorporating civic and educational facilities, shopping centers can fill an existing void." 12 Not only did Gruen and others promote the construction of community centers in the atomized landscape of suburbia, but in appearance their earliest shopping centers idealizedalmost romanticized-the physical plan of the traditional downtown shopping street, with stores lining both sides of an open-air pedestrian walkway that was landscaped and equipped with benches. ${ }^{13}$ (See Figure 3.)

While bringing many of the best qualities of urban life to the suburbs, these new "shopping towns," as Gruen called them, also sought to overcome the "anarchy and ugliness" characteristic of many American cities. A centrally owned and managed Garden State Plaza or Bergen Mall, it was argued, offered an alternative model to the inefficiencies, visual chaos, and provinciality of traditional downtown districts. A centralized administration made possible the perfect mix and "scientific" placement of stores, meeting customers' diverse needs and maximizing store owners' profits. Management kept control visually by standardizing all architectural and graphic design and politically by requiring all tenants to participate in the tenants' association. Common complaints of downtown shoppers were directly addressed: parking was plentiful, safety was ensured by hired security guards, delivery tunnels and loading courts kept truck traffic away from shoppers, canopied walks and air-conditioned stores made shopping comfortable year 'round, piped-in background music replaced the cacophony of the street. The preponderance of chains and franchises over local stores, required by big investors such as insurance companies, brought shoppers the latest national trends in products and merchandising techniques. B. Earl Puckett, Allied Stores' board chair, boasted that Paramus's model shopping centers were making it "one of the first preplanned major cities in America."14 What made this new market structure so unique and appealing to businessmen like Puckett was that it encouraged social innovation while maximizing profit.

Garden State Plaza and Bergen Mall provide good models for how shopping

\footnotetext{
12 Victor Gruen, "Introverted Architecture," Progressive Architecture 38, no. 5 (1957): 204-08; Victor Gruen and Larry Smith, Shopping Towns USA: The Planning of Shopping Centers (New York, 1960), 22-24; both quoted in Gillette, "Evolution of the Planned Shopping Center." For more on Gruen, see Kowinski, Malling of America, 118-20, 210-14; "Exhibit of Shopping Centers," New York Times (October 19, 1954): 42. Paul Goldberger recently profiled shopping-center builder Martin Bucksbaum in "Settling the Suburban Frontier," New York Times Magazine (December 31, 1995): 34-35.

${ }^{13}$ Robert Bruegmann made the same point about the way the earliest design of suburban shopping centers resembled downtown shopping streets in a talk to the Urban History Seminar of the Chicago Historical Society, February 17, 1994.

${ }_{14}$ Quoted in Feinberg, What Makes Shopping Centers Tick, 101. In addition to sources already cited on the control possible in a shopping center versus a downtown, see "Shopping Centers Get 'Personality,'" New York Times (June 29, 1958): 1.
} 


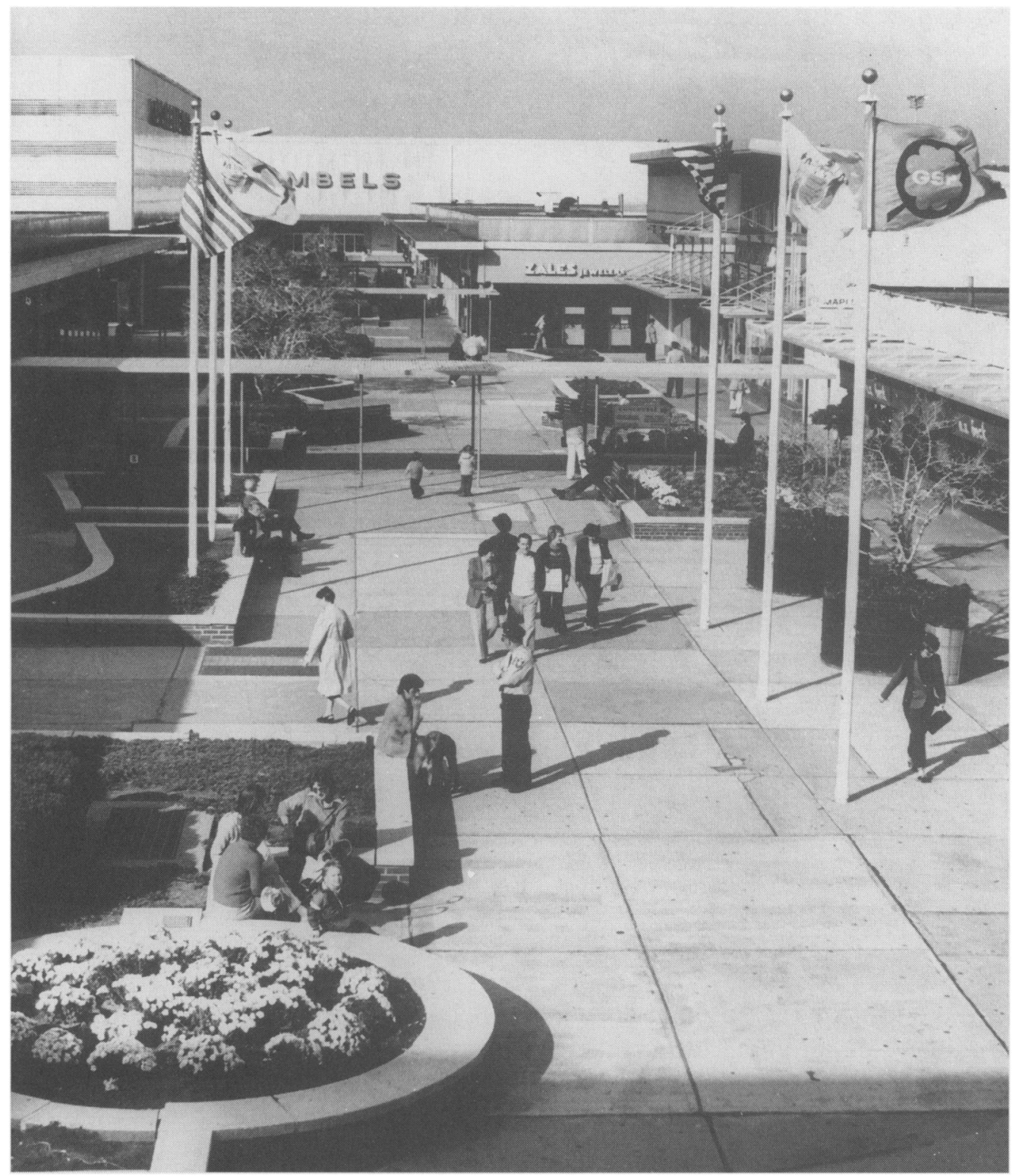

FIGURE 3: Garden State Plaza in the early 1960s featured open-air and landscaped walkways, suggesting a pedestrian Main Street. Courtesy of Garden State Plaza Historical Collection.

centers of the 1950s followed Gruen's prescription and became more than miscellaneous collections of stores. As central sites of consumption, they offered the full range of businesses and services that one would previously have sought downtown. They not only sold the usual clothing and shoes in their specialty and department stores-Sterns and J. J. Newberry at Bergen Mall, Bamberger's (Macy's New Jersey division), J. C. Penney's and Gimbels at Garden State Plaza-but also featured stores specifically devoted to furniture, hardware, appliances, groceries, gifts, drugs, books, toys, records, bakery goods, candy, jewelry, garden supplies, 


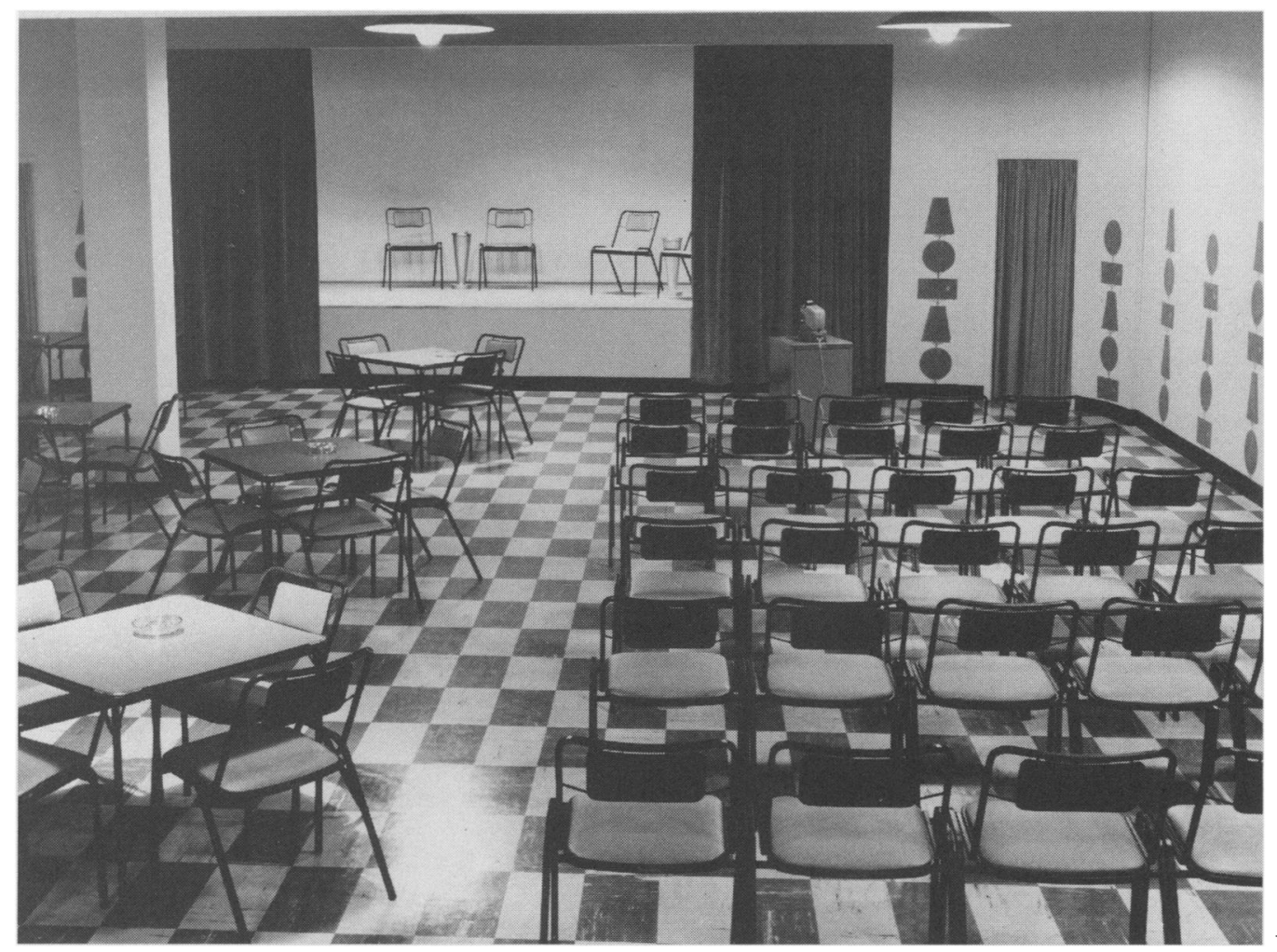

FIGURE 4: The in-house publication Penney News (November-December 1958) published this photo as part of a feature story on the recent opening of J. C. Penney's Garden State Plaza store. The caption read, "This community club room which can also serve as selling area will be made available free of charge to women's clubs and civic groups." Penney's created this community club room, its first ever, as part of the campaign to make the shopping center the heart of suburban life. P-N.J., Paramus-11. Courtesy of JCPenney Archives and Historical Museum, Dallas, Texas.

hearing aids, tires, even religious objects. Services grew to include restaurants, a post office, laundromat, cleaners, key store, shoe repair, bank, loan company, stock brokerage houses, barber shop, travel agency, real estate office, "slenderizing salon," and Catholic chapel. Recreational facilities ranged from a 550-seat movie theater, bowling alley, and ice-skating rink to a children's gymnasium and playground.

Both shopping centers made meeting rooms and auditoriums available to community organizations and scheduled a full range of cultural and educational activities to legitimize these sites as civic centers, which also attracted customers. (See Figure 4.) Well-attended programs and exhibitions taught shoppers about such "hot" topics of the 1950s and 1960s as space exploration, color television, modern art, and civics. Evening concerts and plays, ethnic entertainment, dances and classes for teenagers, campaign appearances by electoral candidates, community outreach for local charities: these were some of the ways that the Bergen Mall and Garden State Plaza made themselves indispensable to life in Bergen County. In sum, it was hard to think of consumer items or community events that could not be found at one or the other of these two shopping centers. (In the 1970s, a cynical reporter 
cracked that "the only institution that had not yet invaded" the modern shopping mall was the funeral home.) Furthermore, stores and services were more accessible than those downtown, as the centers were open to patrons from 10 a.m. to 9:30 p.m., at first four nights a week and by the 1960s, six nights a week. To a regional planner such as Ernest Erber, these postwar shopping centers helped construct a new kind of urbanism appropriate to the automobile age: the "City of Bergen," he named the area in 1960. The New York Times agreed, remarking of the Paramus commercial complex, "It lives a night as well as a day existence, glittering like a city when the sun goes down." 15

When developers and store owners set out to make the shopping center a more perfect downtown, they aimed to exclude from this public space unwanted urban groups such as vagrants, prostitutes, racial minorities, and poor people. Market segmentation became the guiding principle of this mix of commercial and civic activity, as the shopping center sought perhaps contradictorily to legitimize itself as a true community center and to define that community in exclusionary socioeconomic and racial terms. The simple demographics of postwar America helped: when nine of the ten largest cities in the United States lost population between 1950 and 1960 while all metropolitan areas grew, three whites were moving out for every two non-whites who moved in, laying the groundwork for the racially polarized metropolitan populations of today. ${ }^{16}$ In this way, suburbanization must be seen as a new form of racial segregation in the face of a huge wave of African-American migration from the South to the North during the 1950s.

Shopping centers did not exclude inadvertently by virtue of their suburban location. Rather, developers deliberately defined their communities through a combination of marketing and policing. Macy's reminded its stockholders in 1955 as it was building its first shopping center, the Garden State Plaza, "We are a type of organization that caters primarily to middle-income groups, and our stores

15 Ernest Erber, "Notes on the 'City of Bergen," September 14, 1960, Box B, Ernest Erber Papers (hereafter, Erber), Newark Public Library (hereafter, NPL), Newark; "Paramus Booms as a Store Center," New York Times (February 5, 1962): 33-34; “The Mall the Merrier, or Is It?" New York Times (November 21, 1976): 62. For details on particular stores and activities at Bergen Mall and Garden State Plaza, see Feinberg, What Makes Shopping Centers Tick, 97-100; Fogarty, et al., Bergen County, 189; Prosser, "New Downtowns," 119. Almost every issue of the Bergen Evening Record from 1957 and thereafter yields valuable material (in articles and advertisements) on mall stores, services, and activities. The discussion here is based particularly on issues from November 8, 13, and 19, 1957, January 8, 1958, June 10, 1959, and March 2, 1960. Also see "Shoppers! Mass Today on Level 1," New York Times, June 14, 1994; press release on Garden State Plaza's opening in the Historical Collection of Garden State Plaza, folder "GSP history"; "It Won't Be Long Now . . . Bamberger's, New Jersey's Greatest Store, Comes to Paramus Soon," promotional leaflet, stamped August 22, 1956, file "Bergen County Shopping Centers," Johnson Free Public Library, Hackensack, N.J.; "The Shopping Center," New York Times (February 1, 1976): 6-7.

For data on the allocation of shopping-center space in ten regional shopping centers in 1957, see William Applebaum and S. O. Kaylin, Case Studies in Shopping Center Development and Operation (New York, 1974), 101. For evidence of the community orientation of shopping centers nationwide, see Arthur Herzog, "Shops, Culture, Centers-and More," New York Times Magazine (November 18, 1962): 34-35, 109-10, 112-14; in the New York Times: "A Shopping Mall in Suffolk Offering More Than Goods," June 22, 1970: 39; "Supermarkets Hub of Suburbs," February 7, 1971: 58; "Busy Day in a Busy Mall," April 12, 1972: 55. On the community-relations efforts of branch stores, see Clinton L. Oaks, Managing Suburban Branches of Department Stores (Stanford, Calif., 1957), 81-83.

16 George Sternlieb, The Future of the Downtown Department Store (Cambridge, Mass., 1962), 10. 
reflect this in the merchandise they carry and in their physical surroundings." 17 It was this concern for "physical surroundings" that made the setting of the suburban shopping center appealing to retailers-and ultimately to customers. As Baltimore's Planning Council explained more explicitly than merchants ever would, "Greater numbers of low-income, Negro shoppers in Central Business District stores, coming at the same time as middle and upper income white shoppers are given alternatives in ... segregated suburban centers, has had unfortunate implications [for downtown shopping]."18

Store selection, merchandise, prices, and carefully controlled access to suburban shopping centers supported the class and color line. A survey of consumer expenditures in northern New Jersey in 1960-1961 revealed that while 79 percent of all families owned cars, fewer than one-third of those with incomes below $\$ 3,000$ did, and the low-income population included a higher percentage of non-white families than the average for the whole sample. ${ }^{19}$ Although bus service was available for shoppers without cars, only a tiny proportion arrived that way (in 1966, a daily average of only 600 people came to the Garden State Plaza by bus compared to a mid-week daily average of 18,000 cars and a holiday peak of 31,000 cars, many carrying more than one passenger), and bus routes were carefully planned to serve non-driving customers-particularly women-from neighboring suburbs, not lowincome consumers from cities such as Passaic, Paterson, and Newark. ${ }^{20}$ Whereas individual department stores had long targeted particular markets defined by class and race, selling, for example, to "the carriage trade" at the upper end, shopping centers applied market segmentation on the scale of a downtown. In promoting an idealized downtown, shopping centers like Garden State Plaza and Bergen Mall tried to filter out not only the inefficiencies and inconveniences of the city but also the undesirable people who lived there.

\footnotetext{
${ }_{17}$ R. H. Macy \& Company, Annual Report (New York, 1955). The Times-Advocate, March 14, 1976, argues that Bamberger's, Macy's store at the Garden State Plaza, was at the forefront of the chain's appeal to the middle to upper-income shopper. On market segmentation of shopping centers, also see William H. Whyte, Jr., The Organization Man (New York, 1956), 316-17; Jacobs, The Mall, 5, 12; and Albert Bills and Lois Pratt, "Personality Differences among Shopping Centers," Fairleigh Dickinson University Business Review 1 (Winter 1961), which distinguishes between the customers of the Bergen Mall and Garden State Plaza in socioeconomic terms. Crawford's "World in a Shopping Mall," in Sorkin, Variations on a Theme Park, discusses the sophisticated strategies that market researchers use to analyze trade areas and pitch stores to different kinds of customers, 8-9.

18 George Sternlieb, "The Future of Retailing in the Downtown Core," AIP Journal 24 (May 1963), as reprinted in Howard A. Schretter, Downtown Revitalization (Athens, Ga., 1967), 95, and quoted in Jon C. Teaford, The Rough Road to Renaissance: Urban Revitalization in America, 1940-1985 (Baltimore, Md., 1990), 129.

${ }^{19}$ United States Department of Labor, Bureau of Labor Statistics, "Consumer Expenditures and Income, Northern New Jersey, 1960-61," BLS Report No. 237-63, December 1963, Schomburg Center, New York Public Library, Clipping File "Consumer Expenses \& Income-NJ."

20 "The Wonder on Routes 4 and 17: Garden State Plaza," brochure, file "Bergen County Shopping Centers," Johnson Free Public Library, Hackensack, New Jersey; "Notes on Discussion Dealing with Regional (Intermunicipal) Planning Program for Passaic Valley Area (Lower Portion of Passaic Co. and South Bergen," n.d., Box A, Folder 3, Erber, NPL; "Memorandum to DAJ and WBS from EE," November 22, 1966, Box B, Erber, NPL; National Center for Telephone Research (A Division of Louis Harris and Associates), "A Study of Shoppers' Attitudes toward the Proposed Shopping Mall in the Hudson County Meadowlands Area," conducted for Hartz Mountain Industries, February 1979, Special Collections, Rutgers University, New Brunswick, New Jersey.
} 
IF DEVELOPERS AND RETAILERS ENVISIONED the regional shopping center as the new American city of postwar suburbia, what actually happened? How successful were shopping centers in attracting patrons and displacing existing urban centers? By investigating the behavior of consumers, on the one hand, and retail businessmen on the other, we can assess the impact of Bergen Mall and Garden State Plaza on the commercial and community life of Bergen County.

Consumer surveys of the late 1950 s and early 1960 s, carried out by sociologists and market researchers interested in evaluating the changes wrought by the new regional shopping centers, provide a remarkably good picture of consumer behavior in the era. Before the Bergen Mall and Garden State Plaza opened in 1957, Bergen County shoppers satisfied their immediate needs on the main streets of Hackensack and of smaller surrounding towns such as Ridgewood, Fair Lawn, Bergenfield, and Englewood. For more extensive shopping, people went to branches of Sears and Arnold Constable in Hackensack, Meyer Brothers and Quackenbush's department stores in Paterson, Bamberger's, Hahne's, and Kresge's in Newark, and quite often to the big stores in Manhattan. Even before the regional shopping centers opened, the huge influx of new suburban dwellers had raised retail sales in Bergen County from $\$ 400$ million in 1948 to $\$ 700$ million in 1954 , an increase of 79 percent; by 1958 , sales had increased another 23 percent to $\$ 866$ million. Nonetheless, Bergen County residents in 1954 were still spending $\$ 650$ million outside the county, almost as much as inside. ${ }^{21}$

Samuel and Lois Pratt, professors at Fairleigh Dickinson University, surveyed Bergen County consumers living within a ten-minute drive of the two new shopping centers in 1957, 1958, and 1959 to follow changes in their shopping habits over time. Prior to the opening of the shopping centers, seven in ten suburban families surveyed shopped in New York City to some extent. One year after the centers opened, the numbers shopping in New York dropped to six in ten, and two years after, fewer than five in ten families shopped there at all. In other words, one-fourth of the entire sample formerly had shopped in New York City but had now entirely stopped. The loss was even more substantial than that; the 15 percent of suburban families who formerly did most of their shopping in New York City-people the Pratts labeled "major shoppers"- showed the sharpest decline, 50 percent by 1958, 80 percent by 1959 . Moreover, those who continued to shop in New York City were spending much less money there; the average annual expenditure in New York by suburban families dropped from $\$ 93$ to $\$ 68$ after the regional shopping centers opened. Furthermore, consumers were much less likely to shop in the New York stores that had opened suburban branches; by the end of the first year, the number of Bergen County families who had traded in the New York Macy's or Stern's dropped by half. A similar study of 1,100 shoppers by the New York University School of Retailing confirmed the Pratts' findings: shoppers for women's wear were half as likely to go to New York and a third as likely to go to Hackensack just one year after the shopping centers had opened. By the early 1960s, a survey of New York area shoppers by a Harvard Business School professor concluded that more than 80 percent of residents of the New Jersey suburbs were most likely to shop

${ }^{21}$ Stuart, Our Era, 20; Lois Pratt, "The Impact of Regional Shopping Centers in Bergen County," unpublished conference paper delivered April 23, 1960, in possession of the author. 
close to home for clothing and household items, while only 20 percent went most often to Manhattan and 38 percent to New Jersey cities. (Some multiple answers brought the total over 100 percent.) Nationwide, the trend was the same; retail sales in central business districts declined dramatically between 1958 and 1963, while overall metropolitan sales mushroomed from 10 to 20 percent. $^{22}$

The reasons consumers routinely gave for shifting from downtown stores to shopping centers varied, but the overwhelming motivation they articulated was convenience-the ability to drive and park easily, more night hours, improved store layouts, increased self-selection, and simplified credit like the charge plate. The Pratts concluded that shoppers were not so much dissatisfied with New York and Hackensack stores as attracted to the ease and "progressiveness" of shoppingcenter shopping. People seemed to share the developers' sense that shopping centers were the modern way to consume. ${ }^{23}$

While overall patronage of stores in surrounding downtowns declined as shopping-center patronage increased, researchers discovered that the story was not so simple; some local stores were benefiting as Bergen County residents became less dependent on New York. Small purchases that shoppers would have made alongside larger ones in New York were now handled closer to home, often in locally owned shops in small downtowns. A large town like Hackensack, however, did not benefit as much as a Ridgewood or Englewood, since it was being displaced as a major shopping site by the shopping centers, and its stores were less likely to foster the same kind of loyalty to merchants as shops in small towns. In fact, within a year of the shopping centers' opening, major shoppers used Hackensack a third less; as a consequence, 50 percent of the retail establishments on Main Street reported they had done less business than the previous year. By 1960, 10 percent of the stores on Hackensack's Main Street had closed from competition. Bergen County residents were restructuring their consumption patterns by substituting the new shopping centers for New York and for closer, large shopping towns like

\footnotetext{
$\rightarrow$ Samuel Pratt and Lois Pratt, "The Impact of Some Regional Shopping Centers," Journal of Marketing 25 (October 1960): 44-50; Samuel Pratt, "The Challenge to Retailing," an address to the 1957 Annual Meeting of the Passaic Valley Citizens Planning Association, April 24, 1957, in possession of the author; L. Pratt, "Impact of Regional Shopping Centers in Bergen County"; Samuel Pratt and James Moran, "How the Regional Shopping Centers May Affect Shopping Habits in Rochelle Park (Preliminary)," Business Research Bulletin 1, Bureau of Business Research, Fairleigh Dickinson University (1956); New York University study cited in Thompson, "Suburb That Macy's Built," 196, 200; Regional Plan Association, Committee on the Second Regional Plan, "Work Book for Workshops," Princeton, N.J., May 25-26, 1966, Box D, pp. V-7-9, Erber, NPL; Stuart U. Rich, Shopping Behavior of Department Store Customers: A Study of Store Policies and Customer Demand, with Particular Reference to Delivery Service and Telephone Ordering (Boston, 1963), esp. 133-56, 228; Plan One Research Corporation, New York City, for the Bergen Evening Record Corporation, The Mighty Market (Hackensack, N.J., 1971). For national statistics on the decline of retail sales in central business districts while they mushroomed in metropolitan areas between 1958 and 1963, see Teaford, Rough Road to Renaissance, 129-31.

${ }^{23}$ Pratt and Moran, "How the Regional Shopping Centers May Affect Shopping Habits in Rochelle Park"; Pratt, "Challenge to Retailing," 13-15. For surveys of consumers outside of the New York area, see C. T. Jonassen, Downtown versus Suburban Shopping, Ohio Marketing Studies, The Ohio State University Special Bulletin Number X-58 (Columbus, Ohio, 1953); Sternlieb, Future of the Downtown Department Store, 33, 131-33; Rich, Shopping Behavior of Department Store Customers; and several important studies described in Pratt, "Challenge to Retailing," 15-19.
} 


\section{Per Capita Annual Retail Sales, 1939-1967, Paramus and Hackensack, New Jersey}

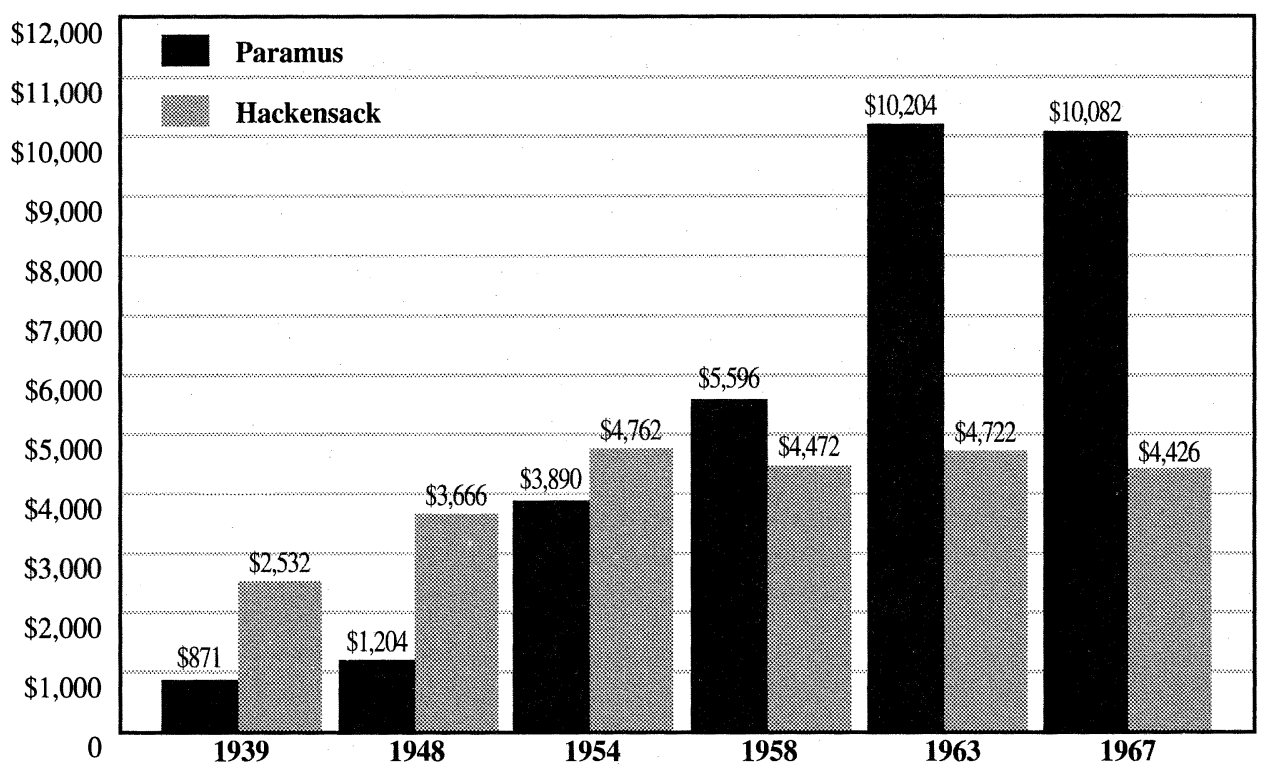

Sources: U.S. Census of Business: Retail Trade-area Statistics, 1939, 1948, 1954, 1958, 1963, 1967; U.S. Bureau of the Census: Census of Population, 1940, 1950, 1960, 1970.

Calculated as: (Total Retail Sales/Consumer Price Index)/Population for Nearest Year. (C) Lizabeth Cohen

FIGURE 5

Hackensack, while continuing to shop-mostly for convenience goods and services-in the small town centers near their homes. ${ }^{24}$ (See Figure 5.)

While it is hard to evaluate the extent to which people viewed the shopping centers as more than places to shop-as community centers-anecdotal evidence suggests that they did. Many reporters writing stories in the late 1950s and 1960s on the way malls were becoming central to the nation's culture made this point, and they routinely introduced their readers to people like Ernest J. Weinhold, a retired designer, who said that he and his wife came to the Cherry Hill Mall in southern New Jersey four days a week. "I love it here-there are things going on that you don't find anywhere else. I don't shop every day but what I do buy I get here." ${ }^{25}$ The general manager of Willowbrook Mall, a shopping center not far from Paramus, explained that the Ernest Weinholds of the suburban world made it easy to program activities about forty-five weeks a year. "Whether it's charity fairs, 4-H exhibits, meetings of the Weight-Watchers or the concert by the local barbershop quartet, we find that people respond-and that's what counts." 26 In the new public place of the shopping center, consuming and leisure were becoming inseparably intertwined,

${ }^{24}$ See all the Pratt studies listed in note 22, as well as "Hackensack Faces Year of Decision," Bergen Evening Record (January 10, 1958): 47.

${ }^{25}$ Herzog, "Shops, Culture, Centers-And More," 110, quote on 114.

26 "The Shopping Centers," New York Times (February 1, 1976): 7. 
constructing community experiences around the cultural tastes of white middleclass suburbanites.

The response of businessmen in the existent town centers of northern New Jersey provides further evidence of the crisis confronting local retailers with the arrival of the shopping centers in the late 1950s. As the openings of the Bergen Mall and Garden State Plaza neared, and particularly once they were a reality, Main Street retailers in Hackensack, Paterson, and other shopping towns told interviewers that they knew they had to improve their own stores and work cooperatively with other merchants to promote downtown. In 1957, Hackensack's Chamber of Commerce launched the first of many campaigns to make shopping in Hackensack more attractive, featuring the covering of downtown meters at Christmas time so customers could park free. Paterson, four miles away, formed the Commercial Development Fund for Paterson's Future, which raised $\$ 65,000$ to promote downtown through marketing and advertising; at the same time, the Municipal Parking Authority issued $\$ 1.8$ million in bonds to double the capacity of Paterson's downtown parking lots, raising the total to 800 . (By contrast, each shopping center offered parking for more than 8,000 cars!)

Despite the best of intentions to ease parking and traffic, make downtown safer, improve customer service, cooperate in promoting downtown shopping, expand merchandise, modernize stores, and strengthen community ties, merchants in Bergen County's town centers had a tough time. Organizing cooperative campaigns of merchants who by identity and practice were independent was extremely difficult. Chambers of Commerce and similar entities lacked the coercive, centralized authority of shopping-center managements. One downtown's promotional campaign, unfortunately, was more likely to draw shoppers away from another town in crisis than from the shopping centers. Paterson's gain through the Commercial Development Fund for Paterson's Future, for example, turned out to be neighboring Fair Lawn's loss, as retail sales there dropped to half their 1954 level by the end of 1958. In the specific case of Hackensack, moreover, the Pratts found in a study of Bergen County retailers that even before the shopping centers opened, the city was in relative decline; although total retail sales grew along with the exploding suburban population, Hackensack's share of the county market decreased from about 20 to 16 percent between 1948 and 1954. Hence, the shopping centers were only the latest blow to provincial merchants who had not figured out how to prosper in a world undergoing so much social and cultural change. ${ }^{27}$

${ }^{27}$ The discussion in the two previous paragraphs on the response of local businessmen to shopping-center development is based on the following sources: "From Now On-Until When?" Bergen Evening Record (December 6, 1957): 6; "Bergen Shoppers Shun New York," Bergen Evening Record (December 19, 1957): 1; "Main Street Making Comeback in Duel with Shopping Centers," New York Times (May 31, 1962): 1; “Malls Threaten Downtown Suburbia," New York Times (December 20, 1972): 92; Samuel Pratt and Lois Pratt, Suburban Downtown in Transition: A Problem in Business Change in Bergen County, New Jersey (Rutherford, N.J., 1958); L. Pratt, "Impact of Regional Shopping Centers in Bergen County."

Articles on Hackensack merchants' struggle to compete include, in the Bergen Evening Record, "A City with Faith: Hackensack Grows," October 29, 1957: 19; "Alma [Anderson-Linden Merchants Association] Continues to Work to Better Shopping Area," December 2, 1957: 35; "The Way of Alma," December 7, 1957: 28; "Life Line to a City's Future: Hackensack Must Plan, Promote," January 10, 1958: 35; "How to Stimulate Business," January 10, 1958: 42; "What's Ahead for Hackensack Business in '58," January 10, 1958: 48; "So the Fight Is Worth Making," January 10, 1958: 58; "Work Together 
Recognizing the limits of what they could do alone, or through their volunteer merchants' organizations, local Bergen County retailers endorsed two strategies for improving their situation, both of which mobilized the authority and resources of government on their behalf. First, they joined a coalition of other interestsincluding churches and citizens concerned with traffic congestion-to pass blue laws prohibiting Sunday sales. If the shopping centers were allowed to open on Sunday, small, family-run stores for whom a seven-day week was a great hardship would suffer a handicap. If all stores were required to close, the score would be somewhat even. "It's easy for the big stores to open, but it's different for the independents," explained the owner of a men's clothing store in Hackensack, adding that he and most of his staff of ten worked six days a week. "We are truly a service store, which consists of all full-time people. If you open seven days, you might have to hire part-timers. Our customers want to find a familiar face. They don't want to hear that the person they expect to see is off today." 28 The best defense that downtown retailers had against the shopping centers-service-would thus be jeopardized.

Losing no time, Paramus prohibited Sunday sales of virtually all goods except "necessities" (food, drugs, gasoline, newspapers) in 1957, the year the shopping centers opened; violators were subject to a $\$ 200$ fine per offense or ninety days in jail, or both, which finally put teeth into a longstanding statute on the state books. Although the merchants in highway shopping centers protested and sued to have the ordinance revoked, arguing all the way to the New Jersey Supreme Court that their ability to compete with stores in neighboring towns was undermined, they lost. Meanwhile, agitation continued for an effective state-wide restriction of Sunday shopping so as not to penalize particular locales with blue laws, and the New Jersey legislature finally agreed to allow counties to hold referenda on the question. In November 1959, voting took place in fifteen of the state's twenty-one counties; twelve counties, including Bergen, voted a Sunday ban into law. Although highway discount stores appealed, the State Supreme Court eventually upheld the law, as did the U.S. Supreme Court indirectly when it ruled in 1961 on four companion cases concerning the constitutionality of Sunday closing laws in Maryland, Massachusetts, and Pennsylvania. The Supreme Court held that such laws did not violate freedom of religion as protected under the First Amendment or the equal protection guarantees of the Fourteenth Amendment and thereby left it to individual states

to Build Business, Chamber Told," January 30, 1958: 3; "Gooding Introduced to City Merchants: First Paid Executive Secretary Will Plan Promotions for Stores," January 30, 1958: 31; "Bohn Rejects Business Role in Tax Boost," June 6, 1959: 9; and "Main Street Is After Money," The Record (March 21, 1968): C1.

On other towns in northern New Jersey, see, in Bergen Evening Record, "O'Neil Proposes Park Garage as Boon to Englewood Stores," October 18, 1957: 25; "Village Preparing Spaces for Parking of 90 Cars" [Ridgewood], November 6, 1957: 33; "Chamber to Try Charge-It Plan" [Ramsey], November 8, 1957: 20; "Ridgewood Storekeepers Act to Attract Holiday Shoppers," November 12, 1957: sect. 2, p. 1; "Chamber President Finds Shopping Off" [Bergenfield], December 27, 1957: 9; "Drop of 5-10\% Reported in Christmas Business" [Dumont], December 31, 1957: 5; "Shop at Local Stores, Kiwanis Members Told" [New Milford], March 2, 1960: 9. For an excellent case study of Lancaster, Pennsylvania's struggle with suburban retail competition and central city decline, see David Schuyler, "Prologue to Urban Renewal: The Problem of Downtown Lancaster, 1945-1960," Pennsylvania History 61 (January 1994): 75-101.

28 "Bergen Wary of Shopping on Sundays," New York Times, September 7, 1993. 
and localities to regulate Sunday selling as they wished. Due, no doubt, to strong advocacy by influential local businessmen, Bergen County was reputed to have made the greatest effort at enforcing blue laws of any county in New Jersey; a local magistrate even ordered that cigarette vending machines in a Howard Johnson restaurant be unplugged on Sunday. Nationwide during the late 1950s and early 1960s, retailers skirmished over Sunday closing laws, not so much defending traditional mores as using the separation of church and state to veil intense struggles over the extent to which discount stores, shopping centers, and chain stores could capture millions of dollars in retail business through restructuring consumer markets. ${ }^{29}$

The second way that downtown business people sought to harness the power of the state in fighting the shopping centers involved the use of federal funds for urban renewal. The 1954 National Housing Act and the 1956 Federal Highway Act made it possible for cities to use urban renewal grants for rehabilitation of commercial areas; the federal government pledged from two-thirds to three-quarters of the cost of acquiring land and demolishing structures. Paterson proved the most aggressive of the cities in Bergen and Passaic counties in pursuing this strategy, joining with at least sixteen other communities in the metropolitan New York area. Dissatisfied with the gains from the Commercial Development Fund's promotional and parking efforts, civic leaders founded PLAN (Paterson Looks Ahead Now) in the early 1960s to redevelop 121 acres at the core of downtown. PLAN implemented a design by Victor Gruen, who had become an early advocate of the revival of downtowns through careful commercial planning, much as he had pioneered the development of regional shopping centers, themselves the source of many cities' economic ills.

Bringing many of the characteristics of Bergen County shopping centers to the Paterson city center, Gruen designed wide, landscaped pedestrian areas, accessible through loop roadways tied in with six parking garages accommodating 4,500 cars. With Uncle Sam committed to footing three-quarters of the \$24 million bill, local civic leaders headed by PLAN president Raymond J. Behrman, owner of a downtown luggage and women's accessories store, worked to reverse a drastic decline: by 1962, the number of Paterson shoppers had fallen to half what it had been in 1940, despite all the population growth in the region. Soon, Hackensack was talking about applying for urban renewal funds as well. But this injection of federal dollars failed as a remedy. In 1971, shopping centers in the Paterson/Passaic

29 Thompson, "Suburb That Macy's Built," 200; Feinberg, What Makes Shopping Centers Tick, 101. The political and legal struggle over establishing blue laws in Paramus and Bergen County can be traced in the Bergen Evening Record, beginning in 1957. The battle continued into recent times, with another Bergen County referendum in November 1993, which upheld the Sunday closing ban. Paramus and Bergen County are among a very few places in New Jersey that still have blue laws on the books. On the recent referendum, see, in the New York Times, "On Sundays, Bergen Shoppers Rest," December 7, 1992; "Bergen Stores Try to Repeal 'Blue Laws," "August 27, 1993: B1; "Bergen Wary of Shopping on Sundays," September 7, 1993: B1; "Malls Wrestle with the Blues," September 26, 1993; and "Both Sides of Aisle Converge over Blue Laws," The Record (October 13, 1993): C3; "Bergen Stores to Stay Closed on Sundays," Star-Ledger, November 3, 1993. On the struggle over blue laws nationwide, including New Jersey, during the late 1950s and 1960s, see Gerald Gunther, Cases and Materials on Individual Rights in Constitutional Law, 3d edn. (Mineola, N.Y., 1981), 1183-84; E. B. Weiss, "Never on Sunday? A Study on Sunday Retailing" (New York: Doyle Dane Bernbach, Inc., 1962), mimeograph, esp. 11, 36-43, 59, 63, 79, 83-84. My thanks to Alexis McCrossen for bringing this last document to my attention. 
metropolitan area captured 79 percent of all retail trade, well beyond the average of 50 percent for the nation's twenty-one largest metropolitan areas. In 1950, Paterson was a major shopping district, while retail in Paramus hardly existed; twenty years later, Paterson found itself suffering from long-term economic decline, ignored by recently constructed parkways, turnpikes, and interstates and facing intense competition from shopping centers, while Paramus was well on its way to becoming one of the largest retail centers in the world. As the segmentation of consumer markets became the guiding principle in postwar commerce, no amount of revitalization could make a city whose population was becoming increasingly minority and poor attractive to the white middle-class shoppers with money to spend. ${ }^{30}$

While local merchants in Bergen and Passaic counties struggled, the big New York and Newark stores developed their own strategy for dealing with the competition from the new suburban shopping centers: they opened branch stores. Rather than be eclipsed by the postwar shift in population, they followed it. By the late 1950s, branch stores-once a rarity-had become a national trend among large department stores. When department stores with annual net sales of $\$ 10$ million or more were considered, the percentage of branch sales skyrocketed from 4 percent of total sales in 1951 to 32 percent by 1959 ; specialty stores with sales over $\$ 1$ million made a comparable shift from 6 percent of sales through branches to 33 percent over the same period. By 1959, the very success of a regional shopping center like Bergen Mall or Garden State Plaza depended on the quality of the department-store branches that served as its anchors. In time, branch stores evolved from small outlets of Fifth Avenue flagship stores into full-fledged department stores carrying a wide range of merchandise. In the early 1970s, in fact, Bergen Mall's Stern Brothers took the dramatic step of closing its New York City stores, investing everything in its more profitable shopping-center branches. Sterns was not alone; by 1976 , branch sales amounted to nearly 78 percent of total departmentstore business nationwide. The huge postwar investment in suburban stores had significant consequences for consumers, for local retailers, and, as we shall see, for department store employees as well. ${ }^{31}$

By the 1960s, the mass-consumption economy had brought about a major restructuring of consumer markets. As retail dollars moved out of major cities and away from established downtowns within suburban areas, regional shopping centers

\footnotetext{
30 "Supermarkets Hub of Suburbs," New York Times (February 7, 1971): 58; "Main Street Making Comeback in Duel with Shopping Centers," New York Times (May 31, 1962): 1; Feinberg, What Makes Shopping Centers Tick, 100-02; Gillette, "Evolution of the Planned Shopping Center," 454-56; "A New Hackensack Sky Line Looms on Drawing Boards," Bergen Evening Record (December 26, 1957): 40; James B. Kenyon, Industrial Localization and Metropolitan Growth: The Paterson-Passaic District (Chicago, 1960), 209-10; Paterson Planning Board and Boorman and Dorram, Inc., Consultants, "Traffic and Transportation Survey, Paterson Master Plan, Report 3, August 1964"; Rutgers University Bureau of Economic Research in contract to New Jersey Dept. of Conservation and Economic Development for the Meadowland Regional Development Agency and the State of New Jersey, "Technical Report No. 1H: Patterns of Urban Growth and Decline," November 1966, Box A, Folder 7, pp. IH-38, 64, Erber, NPL.

${ }_{31}$ Sternlieb, Future of the Downtown Department Store, 33-36; Rich, Shopping Center Behavior of Department Store Customers, 52-54; Editors of Fortune, Changing American Market, 85-86; John Wallis Johnston, The Department-Store Buyer: A View from Inside the Parent-Branch Complexes, Studies in Marketing No. 12 (Austin, Tex., 1969), 25; Jay Scher, Financial and Operating Results of Department and Specialty Stores of 1976 (New York, 1977), cited in Teaford, Rough Road to Renaissance, 208.
} 
became the distinctive public space of the postwar landscape. Suburban populations increasingly looked to the mall for a new kind of community life-consumptionoriented, tightly controlled, and aimed at citizen-consumers who preferably were white and middle class. This commercialization of public space during the postwar era had profound effects, perhaps the most important of which was the struggle to define what kind of political behavior was permissible in the new, privately owned public place.

WHEREAS, AT FIRST, DEVELOPERS had sought to legitimize the new shopping centers by arguing for their centrality to both commerce and community, over time they discovered that those two commitments could be in conflict. The rights of free speech and assembly traditionally safeguarded in the public forums of democratic communities were not always good for business, and they could conflict with the rights of private property owners-the shopping centers-to control entry to their land. Beginning in the 1960s, American courts all the way up to the Supreme Court struggled with the political consequences of having moved public life off the street and into the privately owned shopping center. Shopping centers, in turn, began to reconsider the desirable balance between commerce and community in what had become the major sites where suburbanites congregated. ${ }^{32}$

Once regional shopping centers like the Paramus malls had opened in the 1950s, people began to recognize them as public spaces and to use them to reach out to the community. When the Red Cross held blood drives, when labor unions picketed stores in organizing campaigns, when political candidates campaigned for office, when anti-war and anti-nuclear activists gathered signatures for petitions, they all viewed the shopping center as the obvious place to reach masses of people. Although shopping centers varied in their responses-from tolerating political activists to monitoring their actions to prohibiting them outright-in general, they were wary of any activity that might offend customers. A long, complex series of court tests resulted, culminating in several key Supreme Court decisions that sought to sort out the conflict between two basic rights in a free society: free speech and private property. Not surprisingly, the cases hinged on arguments about the extent to which the shopping center had displaced the traditional "town square" as a legitimate public forum. ${ }^{33}$

The first ruling by the Supreme Court was Amalgamated Food Employees Union Local 590 vs. Logan Valley Plaza, Inc. (1968), in which Justice Thurgood Marshall, writing for the majority, argued that refusing to let union members picket the Weis

32 Shopping centers retreated from promoting themselves as central squares and street corners not only because of the free speech issue but also to limit the loitering of young people. New York Times: "Supermarkets Hub of Suburbs," February 7, 1971: 58; "Coping with Shopping-Center Crises, Dilemma: How Tough to Get If Young Are Unruly," March 7, 1971: sect. 3, p. 1; "Shopping Centers Change and Grow," May 23, 1971: sect. 7, p. 1.

33 For a useful summary of the relevant court cases and legal issues involved, see Curtis J. Berger, "PruneYard Revisited: Political Activity on Private Lands," New York University Law Review 66 (June 1991): 633-94; also "Shopping Centers Change and Grow," New York Times (May 23, 1971): sect. 7, p. 1. The corporate shopping center's antagonism to free political expression and social action is discussed in Herbert I. Schiller, Culture Inc.: The Corporate Takeover of Public Expression (New York, 1989), 98-101. 
Markets in the Logan Valley Plaza in Altoona, Pennsylvania, violated the workers' First Amendment rights, since shopping centers had become the "functional equivalent" of a sidewalk in a public business district. Because peaceful picketing and leaflet distribution on "streets, sidewalks, parks, and other similar public places are so historically associated with the exercise of First Amendment rights," he wrote, it should also be protected in the public thoroughfare of a shopping center, even if privately owned. The Logan Valley Plaza decision likened the shopping center to a company town, which had been the subject of an important Supreme Court decision in Marsh vs. Alabama (1946), upholding the First Amendment rights of a Jehovah's Witness to proselytize in the company town of Chickasaw, Alabama, despite the fact that the Gulf Shipbuilding Corporation owned all the property in town. The "Marsh Doctrine" affirmed First Amendment rights over private property rights when an owner opened up his or her property for use by the public. ${ }^{34}$ The stance taken in Logan Valley began to unravel, however, as the Supreme Court became more conservative under President Richard Nixon's appointees. In Lloyd Corp. vs. Tanner (1972), Justice Lewis F. Powell, Jr., wrote for the majority that allowing anti-war advocates to pass out leaflets at the Lloyd Center in Portland, Oregon, would be an unwarranted infringement of property rights "without significantly enhancing the asserted right of free speech." Anti-war leaflets, he argued, could be effectively distributed elsewhere, without undermining the shopping center's appeal to customers with litter and distraction. ${ }^{35}$

The reigning Supreme Court decision today is PruneYard Shopping Center vs. Robbins (1980). The Supreme Court upheld a California State Supreme Court ruling that the state constitution granted a group of high school students the right to gather petitions against the U.N. resolution "Zionism is Racism." The court decided that this action did not violate the San Jose mall owner's rights under the U.S. Constitution. But, at the same time, the court reaffirmed its earlier decisions

${ }^{34}$ On Amalgamated vs. Logan Valley Plaza, see "Property Rights vs. Free Speech," New York Times (July 9, 1972): sect. 7, p. 9; “Amalgamated Food Employees Union Local 590 v. Logan Valley Plaza," 88 S.Ct. 1601 (1968), Supreme Court Reporter, 1601-20; 391 US 308, U.S. Supreme Court Recording Briefs 1967, No. 478, microfiche; "Free Speech: Peaceful Picketing on Quasi-Public Property," Minnesota Law Review 53 (March 1969): 873-82. On Marsh vs. State of Alabama, see 66 S.Ct. 276, Supreme Court Reporter, 276-84. Other relevant cases between Marsh vs. Alabama and Amalgamated vs. Logan Valley Plaza are Nahas vs. Local 905, Retail Clerks International Assoc. (1956), Amalgamated Clothing Workers of America vs. Wonderland Shopping Center, Inc. (1963), Schwartz-Torrance Investment Corp. vs. Bakery and Confectionary Workers' Union, Local No. 31 (1964); with each case, the Warren court was moving closer to a recognition that the shopping center was becoming a new kind of public forum.

35 “4 Nixon Appointees End Court's School Unanimity, Shopping Centers' Right to Ban Pamphleteering Is Upheld, 5 to 4," New York Times (June 23, 1972): 1; "Shopping-Center Industry Hails Court," New York Times (July 2, 1972): sect. 3, p. 7; "Lloyd Corporation, Ltd. v. Donald M. Tanner (1972)," 92 S.Ct. 2219 (1972), Supreme Court Reporter, 2219-37. The American Civil Liberties Union brief went to great lengths to document the extent to which shopping centers have replaced traditional business districts; see "Brief for Respondents," U.S. Supreme Court Record, microfiche, 20-29. See also People's Lobby Brief, U.S. Supreme Court Record, microfiche, 5.

The Supreme Court majority wanted to make it clear that in finding in favor of the Lloyd Center, it was not reversing the Logan Valley decision, arguing for a distinction based on the fact that anti-war leafletting was "unrelated" to the shopping center, while the labor union was picketing an employer. The four dissenting justices, however, were less sure that the distinction was valid and that the Logan Valley decision was not seriously weakened by Lloyd. The important court cases between Amalgamated vs. Logan Valley Plaza and Lloyd vs. Tanner included Blue Ridge Shopping Center vs. Schleininger (1968), Sutherland vs. Southcenter Shopping Center (1971), and Diamond vs. Bland $(1970,1974)$. 
in Lloyd vs. Tanner and Scott Hudgens vs. National Labor Relations Board (1976) that the First Amendment did not guarantee access to shopping malls, and it left it to the states to decide for themselves whether their own constitutions protected such access.

Since PruneYard, state appellate courts have been struggling with the issue, and mall owners have been winning in many more states than they have lost. Only in six states, California, Oregon, Massachusetts, Colorado, Washington, and most recently New Jersey, have state supreme courts protected citizens' right of free speech in privately owned shopping centers. In New Jersey, the courts have been involved for some time in adjudicating free speech in shopping centers. In 1983, the Bergen Mall was the setting of a suit between its owners and a political candidate who wanted to distribute campaign materials there. When a Paramus Municipal Court judge ruled in favor of the mall, the candidate's attorney successfully appealed on the familiar grounds that "there is no real downtown Paramus. Areas of the mall outside the stores are the town's public sidewalks." He further noted that the mall hosted community events and contained a meeting hall, post office, and Roman Catholic chapel. In this case, and in another one the following year over the right of nuclear-freeze advocates to distribute literature at the Bergen Mall, free speech was protected on the grounds that the mall was equivalent to a town center. ${ }^{36}$

Such suits should be unnecessary (at least for a while) in New Jersey, because in a historic decision in December 1994 the New Jersey Supreme Court affirmed that the state constitution guaranteed free speech to opponents of the Persian Gulf War who wanted to distribute leaflets at ten regional malls throughout the state. Writing for the majority, Chief Justice Robert N. Wilentz confirmed how extensively public space has been transformed in postwar New Jersey:

The economic lifeblood once found downtown has moved to suburban shopping centers, which have substantially displaced the downtown business districts as the centers of commercial and social activity ... Found at these malls are most of the uses and activities citizens engage in outside their homes ... This is the new, the improved, the more attractive downtown business district-the new community-and no use is more closely associated with the old downtown than leafletting. Defendants have taken that old downtown away from its former home and moved all of it, except free speech, to the suburbs.

Despite the New Jersey Supreme Court's commitment to free speech, it nonetheless put limits on it, reaffirming the regional mall owners' property rights. Its ruling allowed only the distribution of leaflets-no speeches, bullhorns, pickets, parades, demonstrations, or solicitation of funds. Moreover, the court granted owners broad

${ }^{36}$ Berger, "PruneYard Revisited"; Kowinski, Malling of America, 196-202, 355-59; "Shopping Malls Protest Intrusion by Protesters," New York Times (July 19, 1983): B1; “Opening of Malls Fought," New York Times (May 13, 1984): sect. 11 (New Jersey), 7; "Michael Robins v. PruneYard Shopping Center (1979)," 592 P. 2nd 341, Pacific Reporter, 341-51; "PruneYard Shopping Center v. Michael Robins," 100 S.Ct. 2035 (1980), Supreme Court Reporter, 2035-51; U.S. Supreme Court Record, PruneYard Shopping Center vs. Robins (1980), microfiche. The most important Supreme Court case between Lloyd vs. Tanner and PruneYard was Scott Hudgens vs. National Labor Relations Board (1976), where the majority decision backed further away from Logan Valley Plaza and refused to see the mall as the functional equivalent of downtown. "Scott Hudgens v. National Labor Relations Board," 96 S.Ct. 1029 (1976), Supreme Court Reporter, 1029-47. 
powers to regulate leaflet distribution by specifying days, hours, and areas in or outside the mall permissible for political activity. Thus, although shopping centers in New Jersey and five other states have been forced to accommodate some political activity, they have retained authority to regulate it and are even finding ways of preventing legal leafletters from exercising their constitutional rights, such as by requiring them to have million-dollar liability policies, which are often unobtainable or prohibitively expensive. In many other states, shopping centers have been able to prohibit political action outright, much as they control the economic and social behavior of shoppers and store owners. ${ }^{37}$

An unintended consequence of the American shift in orientation from public town center to private shopping center, then, has been the narrowing of the ground where constitutionally protected free speech and free assembly can legally take place. As Justice Marshall so prophetically warned in his Lloyd vs. Tanner dissent in 1972, as he watched the Berger court reverse many of the liberal decisions of the Warren court,

It would not be surprising in the future to see cities rely more and more on private businesses to perform functions once performed by governmental agencies ... As governments rely on private enterprise, public property decreases in favor of privately owned property. It becomes harder and harder for citizens to communicate with other citizens. Only the wealthy may find effective communication possible unless we adhere to Marsh v. Alabama and continue to hold that "the more an owner, for his advantage, opens up his property for use by the public in general, the more do his rights become circumscribed by the statutory and constitutional rights of those who use it." 38

And yet, as Marshall's dissent hinted, and as New Jersey Supreme Court Justice Marie Garibaldi further spelled out, even while advocates for freedom of speech rightfully insist that private property owners respect free speech because their malls have become the new public places, ironically they are endorsing a restructuring of community that could undermine democratic freedom. In the words of Garibaldi's dissent, "Under the majority's theory, private property becomes municipal land and private property owners become the government." The recent growth of self-taxing districts to clean, police, and upgrade neighborhoods, free of municipal oversight or public accountability, suggests some of the worrisome directions American society may be headed as once-public spaces and services become privatized. ${ }^{39}$

37 "Court Protects Speech in Malls," New York Times (December 21, 1994): A1; "Big Malls Ordered to Allow Leafletting," Star-Ledger (December 21, 1994): 1; "Now, Public Rights in Private Domains," New York Times (December 25, 1994): E3; "Free Speech in the Mall," New York Times (December 26, 1994): 38; Frank Askin, "Shopping for Free Speech at the Malls," 1995, unpublished ms. in possession of the author.

38 Marshall dissent, Lloyd vs. Tanner, 92 S.Ct. 2219 (1972), Supreme Court Reporter, 2237.

${ }^{39}$ New York Times: "Business Districts Grow at Price of Accountability," November 20, 1994: A1; "Now, Public Rights in Private Domains," December 25, 1994: E3; “Goon Squads' Prey on the Homeless, Advocates Say," April 14, 1995: B1; "City Council Orders Review of 33 Business Improvement Districts," April 19, 1995: B1; "When Neighborhoods Are Privatized," November 30, 1995. A 1992 Supreme Court ruling, written by Justice Clarence Thomas, strengthened the hand of private property owners like the Lechmere store chain in keeping out union organizers. The decision has led malls to ban Salvation Army bell ringers at holiday time in order to protect themselves against union claims to equal access. "A New Grinch Turns Up at the Mall," New York Times (December 18, 1995): A12. 
AlONG WITH TRENDS TOWARD COMMERCIALIZATION and privatization, the shift from downtown to shopping center entailed a feminization of public space. For at least the last two centuries, American women have been the major shoppers in their families. That pattern continued in the postwar period, with marketers estimating that women not only took on anywhere from 80 to 92 percent of the shopping but also spent a great deal of their time at it. ${ }^{40}$ In a noteworthy departure from earlier times, however, the era of the shopping center saw significant public space-in private hands-being tailored to women's needs and desires as consumers. While the department store born of the nineteenth century created similarly feminized space, the urban commercial district of which it was a part catered as much to male consumption, leisure, and associational life-through bars, clubs, pool halls, and smoke shops, to say nothing of the male-dominated street resulting from the mix of commercial and corporate culture downtown. The shopping center, in contrast, created the equivalent of a downtown district dedicated primarily to femaleorchestrated consumption. ${ }^{41}$

Shopping centers were planned with the female consumer in mind. As women patrons increasingly drove their own cars, they found parking spaces at the shopping center designed wider than usual for the express purpose of making it easier for them-many of whom were new drivers-to park..$^{42}$ Women then entered a well-controlled "public" space that made them feel comfortable and safe, with activities planned to appeal especially to women and children. From the color schemes, stroller ramps, baby-sitting services, and special lockers for "ladies' wraps," to the reassuring security guards and special events such as fashion shows, shopping centers were created as female worlds. "I wouldn't know how to design a center for a man," admitted Jack Follet of John Graham, Inc., a firm responsible for many shopping centers. And if New Jersey resident Mrs. Bonnie Porrazzo was any indication, designers like Follet knew what they were doing. Four or five times a week, she visited a shopping center three minutes from her suburban home because, "It's great for women. What else is there to do?"43

Not only did the shopping center pitch itself to women, it sought to empower them as orchestrators of their families' leisure. Marketing surveys revealed that

40 Jonassen, Downtown versus Suburban Shopping, 15; Alan Voorhees, Shopping Habits and Travel Patterns (Washington, D.C., 1955), 6; Rich, Shopping Behavior of Department Store Customers, 61-64; on the long history of women as shoppers, see Steven Lubar, "Men and Women, Production and Consumption," keynote address to the "His and Hers: Gender and the Consumer" conference, Hagley Museum and Library, April 1994. The increasingly sophisticated field of market research addressed itself to motivating the female consumer. An excellent example is Janet L. Wolff, What Makes Women Buy: $A$ Guide to Understanding and Influencing the New Woman of Today (New York, 1958).

${ }^{41}$ My thanks to William Becker and Richard Longstreth, both of George Washington University, for their suggestions on comparing the gendered character of the downtown street to the shopping center. Also see Gunther Barth, City People: The Rise of Modern City Culture in Nineteenth-Century America (New York, 1980); Elaine Abelson, When Ladies Go A-Thieving: Middle-Class Shoplifters in the Victorian Department Store (New York, 198 $\rightarrow$ William Leach, "Transformations in a Culture of Consumption: Women and Department Stores, 1890-1925," Journal of American History 71 (September 1984): 319-42.

42 On women driving, and specifically using a car for shopping, see Rich, Shopping Behavior of Department Store Customers, 84-85, 137-38; L. Pratt, "Impact of Regional Shopping Centers in Bergen County"; Voorhees, Shopping Habits and Travel Patterns, 17.

${ }^{43}$ Herzog, "Shops, Culture, Centers-and More," 35; "Busy Day in Busy Willowbrook Mall," New York Times (April 2, 1972): 55, 65; Harris, Cultural Excursions, 281. 
almost half of all women shopped for four or more people, usually members of their families. With the advent of the suburban malls, they were increasingly bringing those family members along. Female shoppers in Bergen County surveyed by the Pratts in the first few years after the centers opened revealed that four in ten families were spending more time shopping, three in ten were making more shopping trips, two in ten were taking the children more often, and two in ten were including their husbands more frequently than before the malls were built. A study comparing family shopping in downtown Cincinnati with its suburban shopping centers concurred, finding that while 85 percent of downtown patrons shopped alone, only 43 percent of shopping-center patrons were alone; most of them were accompanied by family members. Accordingly, evenings and weekends were by far the busiest time in malls, creating peaks and valleys in shopping that had not affected downtown stores nearly as much. In many suburban centers, more than half the volume of business was done at night. At the Bergen Mall, the peak traffic count was at 8 p.m., and shopping was very heavy on Saturdays as well. A May Company executive described one of the largest problems in branch-store operation: "the biggest day in the suburban store will be ten times the poorest day, instead of five as it usually is downtown." 44

Shopping centers responded with stores and programming specifically designed to appeal to families, to encourage them further to spend leisure time at the mall. William M. Batten, board chair of J. C. Penney, for example, recalled "the broadening of our lines of merchandise and our services to encompass a fuller spectrum of family activity" as the company began building stores in shopping centers rather than on Main Street in the late 1950s and 1960s; only then did Penney's start selling appliances, hardware, and sporting goods and offering portrait studios, restaurants, auto service, and Singer sewing instruction. As families strolled and shopped together at the mall, they engaged in what increasingly was becoming a form of leisure that was female directed and hence bore witness to a wife's or mother's control.45 (See Figure 6.)

Female authority was also enhanced by shopping centers as they became associated with a huge expansion of consumer credit in the postwar era. In 1950, the ratio of credit to disposable income was 10.4 percent, with $\$ 21.5$ billion worth of debt outstanding. By 1960 , the ratio had grown to 16.1 percent, the debt to $\$ 56.1$ billion; a decade later, they had reached 18.5 percent and $\$ 127$ billion, respectively. The trend was apparent in Bergen County. Bamberger's promoted its Garden State Plaza store as offering "a credit plan to suit every need," a choice between Regular

${ }^{44}$ Rich, Shopping Behavior of Department Store Customers, 64, 71-74; L. Pratt, "Impact of Regional Shopping Centers in Bergen County"; Sternlieb, Future of the Downtown Department Store, 27-28, 184; Feinberg, What Makes Shopping Centers Tick, 97; Oaks, Managing Suburban Branches of Department Stores, 72.

45 JCPenney, “An American Legacy, A 90th Anniversary History” (1992), brochure, 22, 25, JCPenney Archives, Dallas, Texas; Mary Elizabeth Curry, Creating an American Institution: The Merchandising Genius of J. C. Penney (New York, 1993), 311-13; William M. Batten, The Penney Idea: Foundation for the Continuing Growth of the J. C. Penney Company (New York, 1967), 17. The opening of the J. C. Penney store in Garden State Plaza in 1958 is featured in a film, The Past Is a Prologue (1961), which is one of several fascinating movies made by the company that have been collected on a video, Penney Premieres, available through the JCPenney Archives. Also see Penney News 24 (November-December 1958): 1, 7, on the new Paramus store, JCPenney Archives; R. H. Macy \& Company, Annual Report for 1957 (New York, 1957), 26. 

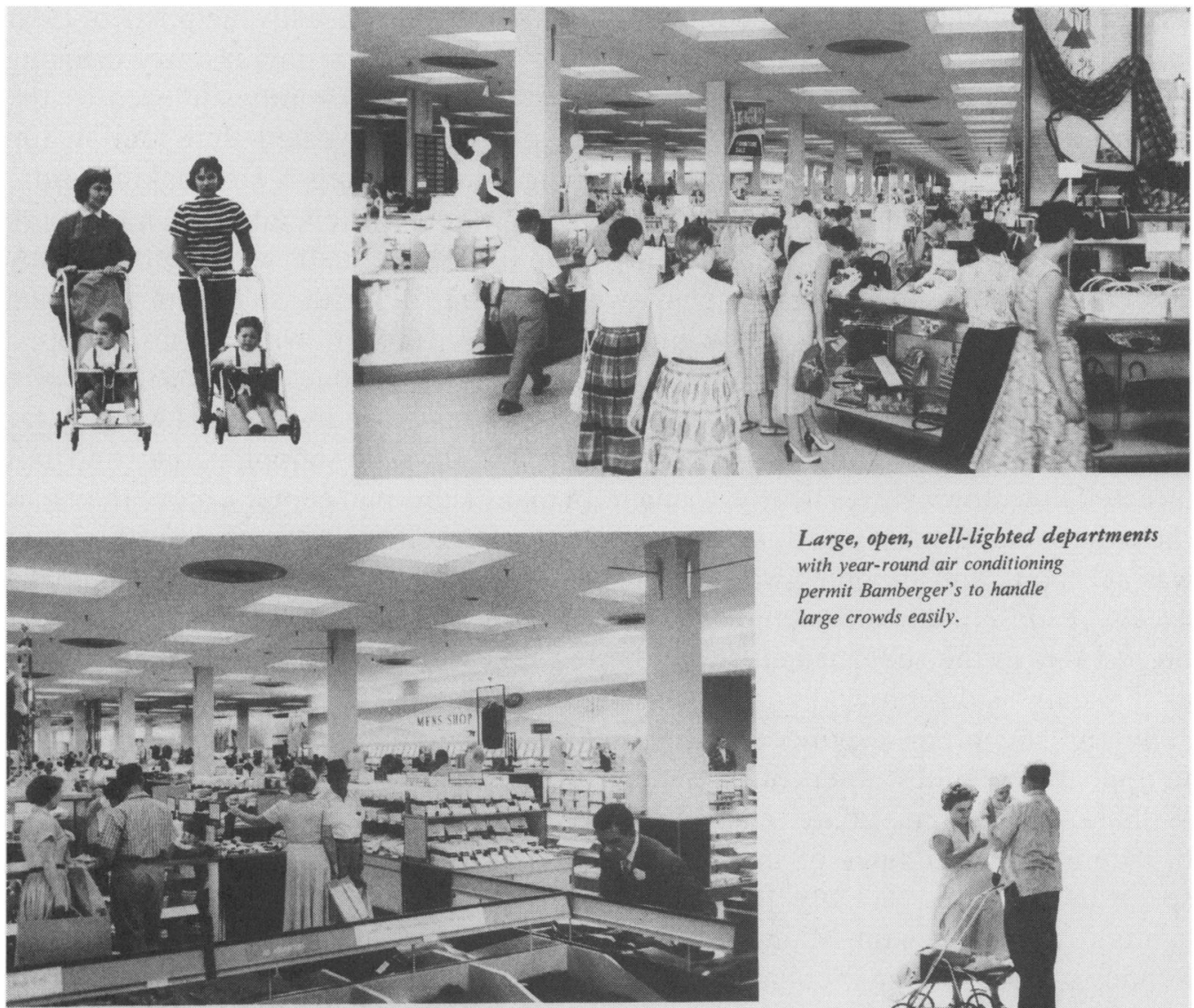

Large, open, well-lighted departments with year-round air conditioning permit Bamberger's to handle large crowds easily.

Do-it-yourself delivery is popular with suburban customers - and so is the "togetherness" of family shopping.

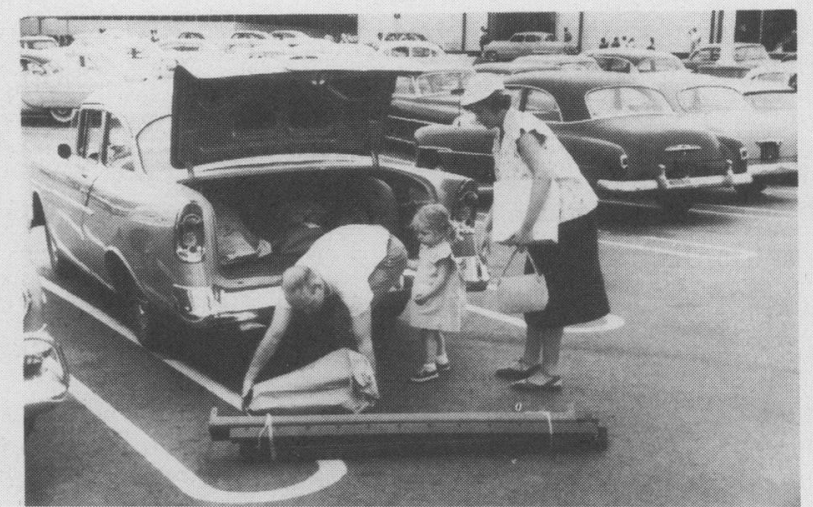

FIGURE 6: This page from Macy's annual report to shareholders the year its Garden State Plaza opened conveys the importance of the female-dominated family market to shopping-center merchandising. Note particularly the invocation of "the 'togetherness' of family shopping" in the bottom caption. Reproduced from R. H. Macy \& Co., Inc., 1957 Annual Report, courtesy of Robert F. Wagner Labor Archives, New York University, from its Department Store Workers-Local 1-S Collection, Box 2, Folder 61. 
Charge Accounts, Budget Charge Accounts, and Deferred Payment Accounts. Once customers came into the store, an innovative teletype hook-up with the Bergen County Credit Bureau enabled charge accounts to be established quickly. Another Garden State Plaza anchor store, J. C. Penney, which had long built its identity around low price, cash-and-carry purchasing, finally recognized in 1957 that credit was expected, even demanded, by consumers, and became the last of the large nationwide retailers to introduce a company credit card. By 1962, national credit facilities and systems were. operating with the latest electronic dataprocessing technology, and charging had become the standard way to buy. As credit cards increasingly became the legal tender of shopping-center purchasing, they expanded women's control over family 'finances from spending the domestic allowance assigned from the weekly or monthly paycheck to committing the family's present and future savings. It should also be noted, however, that credit cards at the same time reinforced women's economic dependence on men, since qualifying generally depended on husbands' or fathers' income, even when women earned money of their own. ${ }^{46}$

As the example of credit cards illustrates, even as women gained power in the family and in the public realm with the emergence of shopping centers, so, too, were their horizons limited by them. Women's public roles were expected to remain defined as consumers, and transcending that role was difficult. The most telling case involved the fate of women as workers in shopping centers like Bergen Mall and Garden State Plaza. As the department stores established branches, they increasingly turned to suburban housewives as retail clerks. The fit seemed perfect. Many women were interested in part-time work, and the stores were looking for part-time labor to service the notorious peaks and valleys in suburban shopping. As a Stanford Business School professor advised branch managers in the year the Bergen County shopping centers opened, "Fortunately, most of these suburban stores have in their immediate neighborhood a large number of housewives and other nonemployed women who have been willing to work during these evening and Saturday peak periods ... Many of these women apparently work as much because of interest as because of economic necessity, and, as a rule, they have proved to be excellent salespeople." The Paramus malls took heed: by the mid-1960s, the

46 Barry Bluestone, Patricia Hanna, Sarah Kuhn, and Laura Moore, The Retail Revolution: Market Transformation, Investment, and Labor in the Modern Department Store (Boston, 1981), 46-47; Rich, Shopping Behavior of Department Store Customers, 100-01; “ 'It Won't Be Long Now . . ': Bamberger's New Jersey's Greatest Store, Comes to Paramus Soon,” stamped August 22, 1956, file "Bergen County Shopping Centers," Johnson Free Public Library, Hackensack; press release, "The Garden State Plaza Opens Wednesday, May 1st at the Junction of Routes 4 and 17, Paramus," Garden State Plaza Historical Collection; JCPenney, “An American Legacy," 21-22; Curry, Creating an American Institution, 305-07.

On the expansion of credit in the postwar period, see Marie de Vroet Kobrak, "Consumer Installment Credit and Factors Associated with It” (M.A. thesis, University of Chicago, 1958); Lewis Mandell, The Credit Card Industry: A History (Boston, 1990); Hillel Black, Buy Now Pay Later (New York, 1961). For a 1971 study documenting the possession of bank cards and store charge cards in the counties of Bergen, Passaic (New Jersey), and Rockland (New York) and when they were last used, see Plan One Research Corporation, Mighty Market, 382-85. In 1958, the Paterson Evening News cited a recent newspaper poll on family finances showing that the wife has full control of the family purse in 90 percent of all families; "Even as You and I," Bergen Evening Record (January 10, 1958): 58; also “Handling Your Money,” January 25, 1958, Bergen Evening Record, Weekend Magazine, 4. 
part-time employment of women had swelled the malls' combined employee ranks to almost 6,000 people, two-thirds of them part-time and many of them local residents. ${ }^{47}$

But according to New York-area labor unions such as Local 1-S, RWDSU (Retail, Wholesale and Department Store Union), which represented employees at Macy's and Bamberger's, and District 65, RWDSU, which represented them at Gimbels, Sterns, and Bloomingdale's, the department stores had another motive for hiring so many part-timers in their new suburban branches: they were trying to cut labor costs and break the hold of the unions, which had organized their New York stores successfully enough to make retail clerking a decent job. Certainly, retailers gave a lot of attention to keeping labor costs down, judging them to be the greatest obstacle to higher profits. Suburban branch managers sought to limit the number of salespeople needed by depending more on customer self-service and "pipe-racking," putting goods on floor racks rather than behind counters. Some stores, such as Sears Roebuck, Montgomery Ward, and J. C. Penney, expanded their catalog operations. ${ }^{48}$ But the basic strategy of the suburban department store was to control wages through hiring more part-timers at minimum wages and benefits.

Organizing the new suburban branches became a life-and-death struggle for the unions beginning in the 1950s. They recognized that not only was the fate of new branch jobs at stake but, as retail dollars left the city for the suburbs, jobs in the downtown stores were threatened as well. The branch store was becoming, in effect, a kind of runaway shop that undermined the job security, wages, benefits, and working conditions of unionized downtown workers. Local 1-S and District 65 tried all kinds of strategies, such as demanding contract coverage of the new branches when renegotiating their existing contracts with downtown stores; getting permission from the National Labor Relations Board to split the bargaining units within particular branch stores (such as into selling, non-selling, and restaurant) to facilitate organization; assigning downtown store workers to picket suburban branches during strikes and organizing campaigns; and gaining the right for city-store employees to transfer to branches without losing accumulated seniority and benefits.

But still, successful labor organization of the suburban branches proved extremely difficult. Branch-store management at Sterns, Bamberger's, and a Bloomingdale's that opened nearby took an aggressive stand against unionism, harassing and firing employees who showed the least inclination to organize, particularly women. Bill Michelson, executive vice-president of District 65, pointed to the mentality of part-time employees as another obstacle to successful organizing: "The part-timer, usually a housewife in a suburban town, is interested in picking up extra money and does not have deep roots in her job." The large turnover among

47 Oaks, Managing Suburban Branches of Department Stores, 73; "Paramus Booms as a Store Center," New York Times (February 5, 1962): 34; "Sales Personnel Ready to Work," Bergen Evening Record, November 13, 1957.

48 Rich, Shopping Behavior of Department Store Customers, 20; Sternlieb, Future of the Downtown Department Store, 27; R. H. Macy \& Company, Annual Report for 1955, 29; JCPenney, "An American Legacy," 25; Stuart, Our Era, 20. 
part-time workers-through lay-offs as well as voluntary resignation-made organizing them all the harder. ${ }^{49}$

Despite the determined efforts of Local 1-S and District 65 to organize all department store workers in the Paramus shopping centers, Gimbels was the only store to sign a union contract that covered its Paramus store, and this in exchange for a lesser wage increase and the cancellation of a threatened strike. At all the rest, an overwhelmingly female work force worked part-time at minimum wage, with few benefits, no union representation, and limited opportunities for career advancement. (See Figure 7.) Work became a way for women to maintain their status as consumers, but it did not significantly empower them as producers who could contribute substantially to-or be independent of-male earnings. At Bamberger's, in fact, the handbook for new employees urged them to use their staff discount to purchase store merchandise (20 percent off for apparel worn on the job, 10 percent on other items) so they could serve as model consumers for customers. The shopping center, then, contributed to a segmentation not only of consumers but of workers as well in a postwar labor market that offered new jobs to women but marked these jobs as less remunerative and more dead-end. ${ }^{50}$ Furthermore, as a workplace, much like as a public space, the shopping center constricted the rights available to the people who frequented it. That women came to dominate the ranks of workers and consumers there meant that their political freedom was particularly circumscribed. The shopping center thus posed a contradiction for women in the 1950s and 1960s: it empowered them in their families through creating a new community setting catering to female needs and desires, yet it contained them in the larger society as consumers and part-time workers. In this era before feminist revolt and affirmative action opened other opportunities, women's choices were limited not simply through peer pressure and personal priorities, as is often claimed, but also through the larger economic restructuring taking place in the metropolitan marketplace.

MASS CONSUMPTION IN POSTWAR AMERICA created a new landscape, where public space was more commercialized, more privatized, and more feminized within the

${ }^{49}$ My understanding of labor conditions and organizing in the New York area, and in the Paramus malls specifically, comes from two manuscript collections at the Robert F. Wagner Labor Archives, New York University: the papers of Local 1-S, Department Store Workers' Union (RWDSU), and District 65, now of the UAW, then of the RWDSU. I have based my analysis on the clippings, meeting minutes, and legal files in those collections, which I have not cited individually unless I quoted from them. Michelson quote from "NLRB Ruling Spurs New York Area Union: Target-50 Stores," Box 4, Folder 36, District 65; similar statement with two-thirds figure from "Report to General Council Meeting, Department Store Section, by William Michelson," January 12, 1965, Box 5, Folder 4, District 65. On department store efforts with part-timers, see "Part-Timer: New Big Timer," Women's Wear Daily, January 8, 1964, Box 4, Folder 35, Local 1-S; also see the records of a fascinating case that Local 1-S brought before the NLRB concerning the firing of a young woman employee who had shown interest in the union: Box 9, Folder 21, Local 1-S.

On industrial relations in department stores nationally, with a case study of the Boston metropolitan area, see Bluestone, et al., Retail Revolution, 70, 80-119, 148-49, which provides an excellent analysis of the restructuring of the labor market in the retail trade. Also see Jacobs, The Mall, 49.

50 Bamberger's Paramus, "Welcome to New Friends and a New Career," Employee Handbook, 1957, Box 7, Folder 16, pp. 4, 9-12, Local 1-S. 


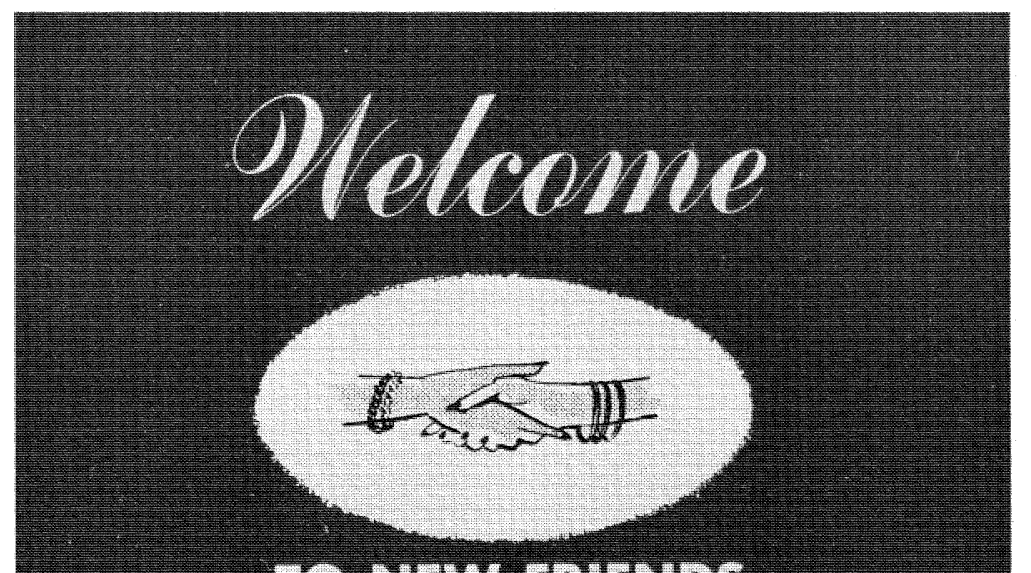

\section{TO NEW FRIENDS}

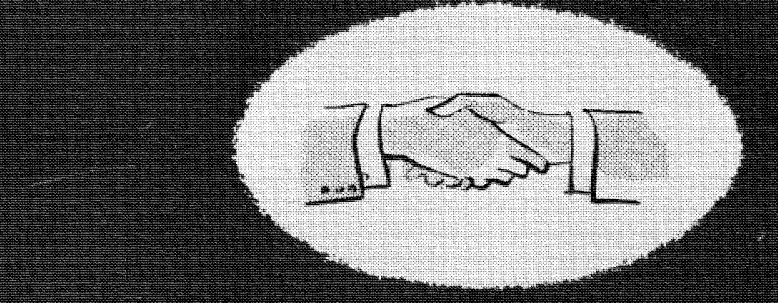

\section{AND A NEW CARER}

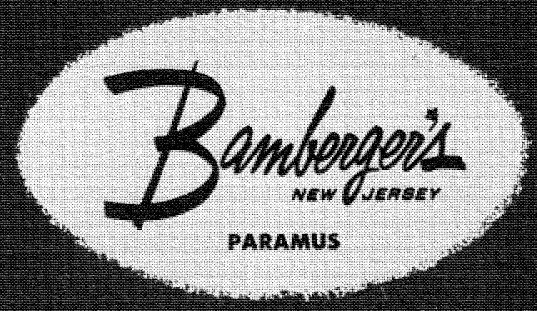

\section{NEW JERSEYS CREATEST STORE ONE OF AMERICAS FINEST}

FIGURE 7: Bamberger's Department Store prepared an employee handbook, of which this is the cover, for the opening of its Garden State Plaza store in 1957. Hoping to recruit part-time female employees among housewives in neighboring suburban towns, the store offered them "new friends," while male applicants were promised "a new career." Courtesy of Robert F. Wagner Labor Archives, New York University, from its Department Store Workers, Local 1-S Collection, Box 7, Folder 16.

regional shopping center than it had been in the traditional downtown center. This is not to romanticize the city and its central business district. Certainly, urban commercial property owners pursued their own economic interests, political activity in public spaces was sometimes limited, and the priorities of women and men did not always peacefully coexist. Nonetheless, the legal distinction between public and private space remained significant; urban loitering and vagrancy laws directed against undesirables in public places have repeatedly been struck down by the courts, while privately owned shopping centers have been able to enforce trespass- 
ing laws. ${ }^{51}$ Overall, an important shift from one kind of social order to another took place between 1950 and 1980, with major consequences for Americans. A free commercial market attached to a relatively free public sphere (for whites) underwent a transformation to a more regulated commercial marketplace (where mall management controlled access, favoring chains over local independents, for example) and a more circumscribed public sphere of limited rights. Economic and social liberalism went hand in hand and declined together.

Not by accident, public space was restructured and segmented by class and race in New Jersey, as in the nation, just as African Americans gained new protections for their right of equal access to public accommodations. Although civil rights laws had been on the books in New Jersey since the late nineteenth century, comprehensive legislation with mechanisms for enforcement did not pass until the 1940s. With the "Freeman Bill" of 1949, African Americans were finally guaranteed equal access to schools, restaurants, taverns, retail stores, hotels, public transportation, and facilities of commercial leisure such as movie theaters, skating rinks, amusement parks, swimming pools, and beaches, with violators subject to fines and jail terms. Throughout the 1940s and 1950s, African-American citizens of New Jersey-and other northern states-vigilantly challenged discrimination by private property owners. Yet larger structural changes in community marketplaces were under way, financed by private commercial interests committed to socioeconomic and racial segmentation. While African Americans and their supporters were prodding courts and legislatures to eliminate legal segregation in public places, real-estate developers, retailers, and consumers were collaborating to shift economic resources to new kinds of segregated spaces. ${ }^{52}$

The landscape of mass consumption created a metropolitan society in which people were no longer brought together in central marketplaces and the parks, streets, and public buildings that surrounded them but, rather, were separated by class, gender, and race in differentiated commercial sub-centers. Moreover, all commercial sub-centers were not created equal. Over time, shopping centers became increasingly class stratified, with some like the Bergen Mall marketing themselves to the lower middle class, while others like the Garden State Plaza went upscale to attract upper middle-class consumers. If tied to international capital, some central business districts-such as New York and San Francisco-have prospered, although they have not been left unscarred from recent retail mergers and leveraged buy-outs. Other downtowns, such as Hackensack and Elizabeth, New Jersey, have become "Cheap John Bargain Centers" serving customers too poor

51 "Amtrak Is Ordered Not to Eject the Homeless from Penn Station," New York Times (February 22, 1995): A1.

52 Article on passage of New Jersey Civil Rights Bill, New York Times, March 24, 19. $\rightarrow$ Marion Thompson Wright, "Extending Civil Rights in New Jersey through the Division Against Discrimination," Journal of Negro History 38 (1953): 96-107; State of New Jersey, Governor's Committee on Civil Liberties, "Memorandum on Behalf of Joint Council for Civil Rights in Support of a Proposed Comprehensive Civil Rights Act for New Jersey," 1948, II, B 8, Folder “Civil Rights, New Jersey, 1941-48," NAACP Papers, Library of Congress, Washington, D.C.; "Report of Legislative Committee, NJ State Conference of NAACP Branches," March 26, 1949, II, B 8, Folder "Civil Rights, New Jersey, 1941-48," NAACP Papers. Other NAACP files on discrimination document the actual experiences of African Americans in New Jersey during the 1940s and 1950s. 
and deprived of transportation to shop at malls. Even in larger American cities, poor urban populations shop downtown on weekends while the white-collar workers who commute in to offices during the week patronize the suburban malls closer to where they live. Some commercial districts have been taken over by enterprising, often newly arrived, ethnic groups, who have breathed new life into what would otherwise have been in decay, but they nonetheless serve a segmented market. Worst off are cities like Newark, once the largest shopping district in the state, which saw every one of its major department stores close between 1964 and 1992 and much of its retail space remain abandoned, leaving residents such as Raymond Mungin to wonder, "I don't have a car to drive out to the malls. What can I do?" Mass consumption was supposed to bring standardization in merchandise and consumption patterns. Instead, diverse social groups are no longer integrated into central consumer marketplaces but rather are consigned to differentiated retail institutions, segmented markets, and new hierarchies. ${ }^{53}$

Finally, the dependence on private spaces for public activity and the more recent privatization of public space gravely threaten the government's constitutional obligations to its citizens. Not only freedom of speech and public assembly in shopping centers are at issue. Just recently, Amtrack's Pennsylvania Station in New York City tried to stave off two suits requiring it to respect constitutional rights guaranteed in public places: an effort by artist Michael Lebron to display a political message on the gigantic curved and lighted billboard that he had rented for two months, and a case brought by the Center for Constitutional Rights to force Amtrak to stop ejecting people from the station because they are homeless. ${ }^{54}$ When Jürgen Habermas theorized about the rise and fall of a rational public sphere, he recognized the centrality in the eighteenth and nineteenth centuries of accessible urban places-cafés, taverns, coffeehouses, clubs, meeting houses, concert and lecture halls, theaters, and museums - to the emergence and maintenance of a democratic political culture. Over the last half-century, transformations in America's economy and metropolitan landscape have expanded the ability of many people to participate in the mass market. But the commercializing, privatizing, and segmenting of physical gathering places that has accompanied mass consumption

\footnotetext{
53 "Closing of 'Last' Department Store Stirs Debate on Downtown Trenton," Star-Ledger, June 5, 1983; "Urban Areas Crave Return of Big Markets," Star-Ledger, July 17, 1984; "Elizabeth Clothier Mourns Demise of Century-Old Customized Service," Sunday Star-Ledger, January 10, 1988; "President's Report to the Annual Meeting, Passaic Valley Citizens Planning Association," Box A, Folder 3, Erber, NPL. On Newark, see for Raymond Mungin quotation, "Two Guys Will Be Missed," Star-Ledger, November 23, 1981. Also see "Last-Minute Bargain Hunters Abound as Chase Closes Up," Newark News, February 12, 1967; "Ohrbach's Will Close Store in Newark, Cites Drop in Sales and Lack of Lease," New York Times, December 7, 1973; and, in the Star-Ledger, "S. Klein to Shut Last State Stores Sometime in June," May 9, 1975; "Sears to Shut Newark Store," June 13, 1978; "Hahne's Bids a Farewell to Newark," June 18, 1986; "Macy's to Shut Stores in Newark, Plainfield," May 21, 1992; "Newmark \& Lewis Is Closing 11 Stores," October 15, 1993; Greater Newark Chamber of Commerce, "Survey of Jobs and Unemployment," May 1973, NPL "Q" File; Greater Newark Chamber of Commerce, "Metro New Jersey Market Report" [1991], NPL "Q” File.

54 "Amtrak Can Be Sued on Poster, Court Rules," New York Times (February 22, 1995): B4; “Amtrak Is Ordered Not to Eject the Homeless from Penn Station," New York Times (February 22, 1995): A1; "Can Amtrak Be a Censor?" Washington Post (February 23, 1995). The Amtrak case was complicated by the ambiguity of Amtrak's status as a government entity or private corporation.
} 
has made more precarious the shared public sphere upon which our democracy depends. ${ }^{55}$

55 Jürgen Habermas, The Structural Transformation of the Public Sphere: An Inquiry into a Category of Bourgeois Society, Thomas Burger trans., with Frederick Lawrence (Cambridge, Mass., 1989); Geoff Eley, "Nations, Publics, and Political Cultures: Placing Habermas in the Nineteenth Century," in Nicholas B. Dirks, Geoff Eley, and Sherry B. Ortner, eds., Culture/Power/History: A Reader in Contemporary Social Theory (Princeton, N.J., 1994), 297-335.

Lizabeth Cohen is a professor of history at New York University, where she teaches twentieth-century U.S. history. She earned her $\mathrm{PhD}$ at the University of California, Berkeley. Her book, Making a New Deal: Industrial Workers in Chicago, 1919-1939 (1990), won the Bancroft Prize in 1991. This article is part of a new book she is currently writing on the political and cultural impact of the mass consumption-oriented economy that prevailed in the United States after World War II. 